\title{
INFLUÊNCIA DA VEGETAÇÃO SOBRE A POPULAÇÃO MICROBIANA E FERTILIDADE DOS SOLOS DE CERRADO
}

\author{
JOSÉ MARIA GUSMAN FERRAZ \\ Biólogo-EMBRAPA
}

Orientador: Dr. Paulo de Campos Torres de Carvalho

Dissertação apresentada à Escola Superior de Agricultura "Luiz de Queiroz", da Universidade de São Paulo, para obłenção do tífulo de Mestre em Microbiologia Agrícola.

$P|R A C| C A B A$

Estado de São Paulo - Brasil Abril, 1978 
- í.

Aos mens pais e imañs. Aos mens avos.

A mintra esposa suely. dedico este trabalho. 


\section{AGRADECIMENTOS}

- Ao Dr. Paulo Campos Torres de Carvalho, pela orientação na realização do presente trabalho.

- A Dra. Elke J. Bran Nogueira Cardoso, pelas sugestöes apre sentadas e pela revisão dos originais.

- Ao Dr. Luiz A. Rochelle pela classificação das plantas de cerrado.

- Ao colega de curso Henry Even Bajungu pela ajuda na versão para o ingles do Resumo.

- Ao Departamento de Fitopatologia da ESALQ-USP, pela permis são do uso de seus laboratórios.

- A Empresa Brasileira de Pesquisa Agropecuária (EMBRAPA] que colaborou para a realização do curso de pós-graduação.

- A minha esposa pela sua compreensão, dedicação e ajuda durante a realização deste trabalho.

- As pessoas e instituições que por lapso involuntário aqui não menciono, os meus agradecimentos. 


\section{INDICE}

pagrina

1. INTRODUÇAO

2. REVISÅD DE LITERATURA $\ldots \ldots \ldots \ldots \ldots \ldots \ldots \ldots \ldots \ldots \ldots \ldots \ldots \ldots \ldots$

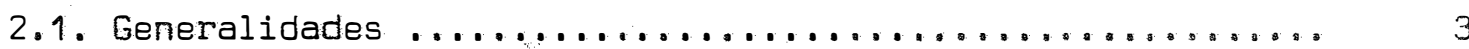

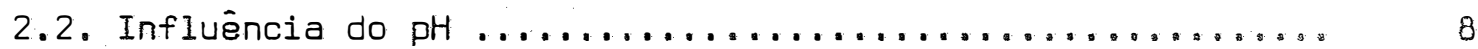

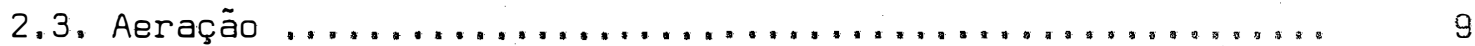

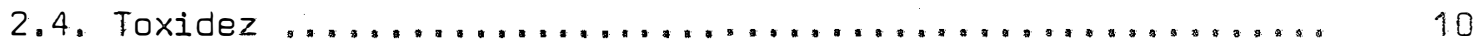

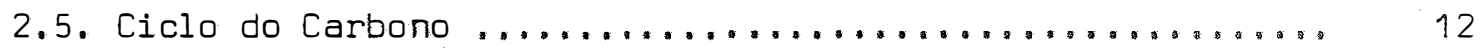

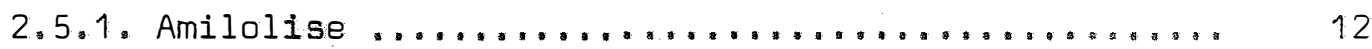

2.5.2. Decomposiçäo da celulose e hemicelulose ......... 13

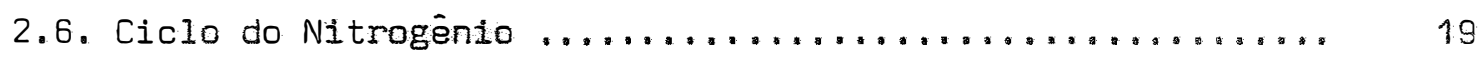

2.6 .1 . Amonificação ......................... 20

2.6.2. Nitrificação ....................... 22

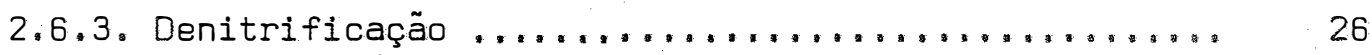

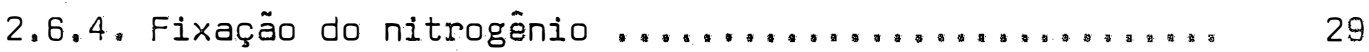

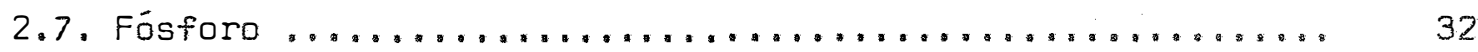

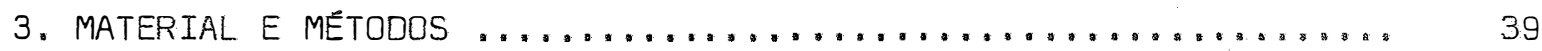

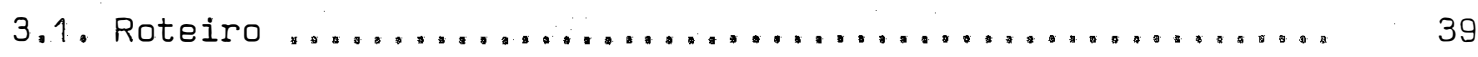

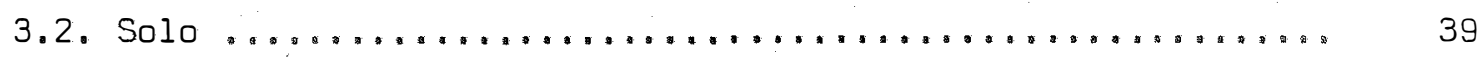

3.3. Matéria Orgänica .......................... 40

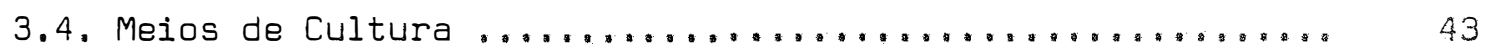

3.5. Coleta do solo, da matéria orgânica e incubação dos värios

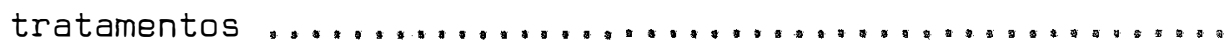




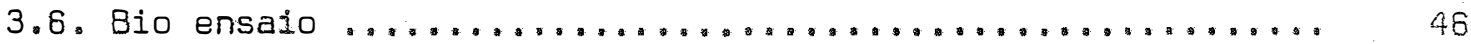

3.7. Incubação com adiçäo de fosfato natural ............ 46

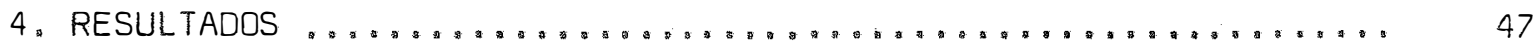

4.1. Avaliação do nümero mais provāvel de microrganismos ...... 47

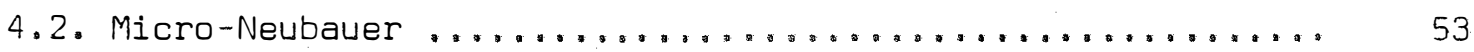

4.3. Avaliação de fósforo solúvel .................... 54

4.4. Análise da fertilidade dos solos .................. 55

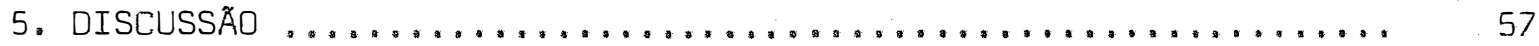

5.1. Número mais provável de microrganismos (ciclo do carbono e

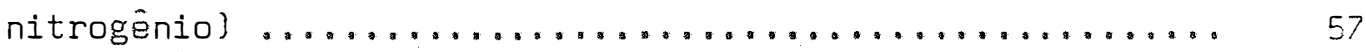

5.2. Micro-Neubauer $\ldots \ldots \ldots \ldots \ldots \ldots \ldots \ldots \ldots \ldots \ldots \ldots \ldots \ldots$

5.3. Análise da fertilidade dos solos .................. 64

5.4. Avaliação do fósforo solüvel .................. 66

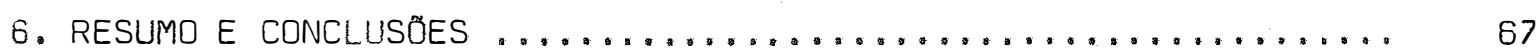

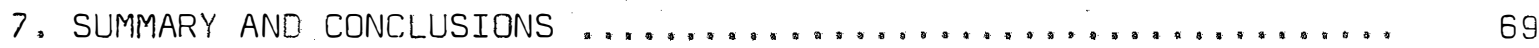

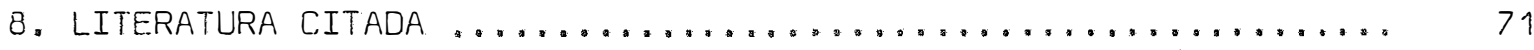

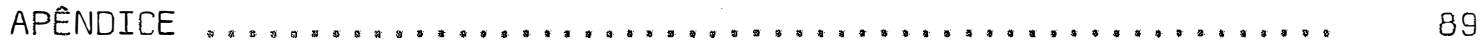




\section{INTRODUÇAO}

Os solos de cerrado no Brasil representam aproximadamente 2 milhões de $\mathrm{km}^{2}$, ärea que expressa a sua importäncia. Conforme o manuseio destas terras, dependerá a sua melhoria ou empobrecimento, pojs processos inadequados as levarão a um empobrecimento ainda maior, ou até mesmo a sua inutilidade total para o aproveitamento agronômíco.

D cerrado natural apresenta um equilibrio entre a vegetaçẽo. solo, mỉcrorganismos e clima e, uma substituição da vegețeça natural por outra podería levar a alterações no ecossistema, que poderiam se refletir negativamente.

A natureza e decomposição dos resíduos orgânicos desempenham um papel importante na formação do solo, e na determinação de suas caracterỉsticas, que dependem de sua constituição mineral, fraçäo orgânica e de atividade microbiana dentre outros. Sabe-se que a apicação de adubos inor gânicos, matéría orgânica, defensivos agrícolas, e mesmo as mais simples técnicas de cultivo e mudanças no tipo de vegetação, iräo resultar numa 
modjificação da flora microbiana do solo. A reciclagem dos nutrientes depen de, essencialmente, da decomposição do liter, que é o princípal responsável pelo equilibrio do ecossistema.

O frequente fracasso da agricultura em certas reglốeş, é um exemplo da necessidade de se levar em conta estas alterações. Muitas vêzes, alguns anos de boa colheita são seguidos de um declineo na produtivida de, e este fracasso se deve ao fato que mecanismos biológicos de retorno, que existiam no ecossistema original, não foram conectados ao sistema orga nizado pelo homem.

o solo de cerrado, sendo um solo senil, äcido, com carências nutricionais e alta cancentração de alumínio, merece além de estudos edafológicos e nutricionals, pesquisas microbiológicas, onde seja levada em consideração a dinâmica microbiana, visando um aumento de sua fertilidade.

O objetivo de nosso trabalho é o de analisar comparativamente os diversos grupos funcionais do ciclo do carbono e do nitrogênio, em solos suplementados com diferentes tipos de matéria orgânica vegetal . Certas áreas de cerrado estão sendo usadas para implantação de reflorestamento, daÍ nosso interesse na utilização de matéria orgânica proveniente da ve getação nativa, comparada com espécies exóticas utilizadas em reflorestamen tos. Os mesmos resíduos orgânicos foram utilizados para verificação de sua influência na solubilização de fosfato natural (fosfato de olinda), em solos incubados. 


\section{REVISATO BIBLIOGRAFICA}

\subsection{General idades}

O estudo dos processos de degradação da matéria orgânica pode ser entendido como o conjunto de numerosos fatôres, de natureza química, física e biológica que, interagindo, determinam certas características no solo em que ocorrem. As transformações das vārias substâncias de origem animal e vegetal em produtos gasosos e residuais, incluindo humus, minerais, água e produtos de síntese são dependentes primariamente, das concìções em que ocorrem e dos microrganismos envolvidos, QUERO (1943), BACON (1968), BROWN, JACKSON e BURLINGHAM (1968). A matéria orgânica presente no solo é variada, compreendendo um grande nümero de moléculas. A fonte principal é de resíduos vegetais que caem no solo e que sofrem trasformações sucessivas, DOMMERGES e MANGENOT (1970), BACON (1968). Desta forma, grandes quantidades de nutrientes podem permanecer em formas orgânicas não disponíveis às plantas até a sua mineralização completa que é levada a cabo

pelos microrganismos, e que pode ser retardada ou acelerada por vários fató res, GREENWOOD (1968), SWABY (s/d) e BACON (1968). 
(1972). quase sempre altera o processo de humificação em função das peculiä ridades da decomposição dos resíduos orgânicos.

A microfauna do solo, tais como microartrópodos, protozoários, anelidos etc., são de grande importância no processo de degradação da matéria orgânica, que além de revolver o material humico e o próprio solo aumentando a aeração e drenagem, eliminam metabólicos que complementam as necessidades alimentares dos mícrorganismos, MACEADYEN (1968). A adição de quitina ao solo, por exemplo, é relatada por MITCHELL, ALEXANDER (1963) como incrementadora do nümero total de bactérias, actinomicetos e organismos produtores de quitinase, além de levar a uma redução de Fusarúum em raízes de feijão em experimentos de casa de vegetação. o micélio e esporos de muitos fungos desaparecem rapidamente quando em contacto com o solo, eviden ciando a sua utilização por outros microrganismos, ALEXANDER (1964), LOCKWOOD (1959), LOCKWOOD E LINDAPA (1963), STEVENSON (1956), KRASILNIKOV (1968) e MITCHELL, ALEXANDER (1963).

No decorrer da decomposição dos restos orgânicos formam-se substâncias coloidais que têm um papel importante no estabelecimento da estrutura e estabilidade do solo, DOMMERGUES e MANGENOT (1970), BACON (1968) e LOVRES, COND e ALENCAR (1976). Uma grande importância é dada à participação dos microrganismos na agregação dos solos, que tem comocausas principa1s: produção e excreção de mucilagem que funciona como agente de cimentação, emaranhado de hifas de fungos e actinomicetos no solo, adsorção na qual as bactérias funcionam como partículas coloidais e com carga negativa, LOURES, CONDE E ALENCAR (1976). 
A vegetação é um fator essencial, determinando a longo prazo a quantidade e a qualidade do humus. Sendo a decomposição dos resîduos vem getais e a mineralização do $C$ e $\mathrm{N}$. dependentes do estado do material adicio nado: material fresco, sêco, fresco e picado, picado e sêco, influenciam di. ferentemente o processo, sendo citado que a adição de matéria fresca estimu la a germinação de esporos bacterianos SCHREVEN (1964), MISHUSTIN e MIRSOßVA (1968) e CALLE e VELASCO (1971).

A maioria dos autores concorda sobre o efeito inibidor que algumas plantas apresentam ao desenvolvimento microbiano de certos grupos funcionais, sendo certo que taninos inibem seletivamente os celulolíticos, CALLE e VELASCO (1971), VELASCO, VILLALBA e CALLE (1974), VELASCO e CALLE (s/d) e BOWEN (1961). Os efeitos de taninos na decomposição de compostos orgânicos são maiores em solos sob florestas do que sob gramíneas, pois a vegetação de floresta contém muito mais tanino do que as de gramíneas, RICE (1964).

Vários trabalhos evidenciaram alterações na microflora de vä rios grupos funcionais, influenciados pela vegetação: VELASCO, VILLALBA e CALLE (1974), constataram a influência de Juniperus thurifera L. e Quercus' ilex L. sp rotundiflia (LANK) Schwartz, na microflora, Utilizando extratos hidrossolúveis destes vegetais, os autores verificaram que em pequenas concen trações eles estimulam o crescimento microbiano, e em concentrações mais al tas, inibem,chegando inclusive a ser nulaparaos fixadores aeróbicos de nitro gênio. Estes resultados confirmam a hipótese de inibição de microrganismos por diversos compostos fenölicos, abordada por CALLE (1968). 
Certos tipos de liter são inibidores de microrganismos, agin do principalmente sobre as bactérias nitrificantes e fixadoras de nitrogênio, pertencentes aos gêneros Azotobacter e Beijerinckia, sendo partícularmente marcante nas coniferas, BAUZON et alii (1969), citado por TOSIN (1977), CALLE e VELASCO (1972), estudaram as alterações na população microbiana em um solo onde havia um povoamento antigo de Quercus toza, reflorestado com Pínus pinaster, e usaram como testemunha o plantio remanescente de Quercus toza. Neste trabalho, evidenciou-se uma influência negativa da nova vegetação de $P$. pinaster sobre a flora total de actinomicetos e, ao contrário, a forte acidificação do solo devido à implantação de espécie resino sa, provocou uma maior prolifferação de fungos. Foram observadas também, alterações nos grupos funcionais dos ciclos do C e N. Dutro exemplo é dado por TOSIN et alii (1976) e TOSIN (1977) analisando a influência da vegetação sobre a microflora do solo, e concluiram que a substituição da mata nativa por Araucaria angustífolia e Pinus elliottie induziu alteraçöes na fertilidade do solo, resultando num aumento acentuado de alumínio e redução da matéria orgânica, cälcio, magnésio e potássio. D pH do solo foi também diminuido em comparação com a mata nativa. No ciclo do nitrogênio, nos plantios de Pinus e Araucaria, as microfloras nitrificantes e denitrificantes diminuiram, e obserbou-se um aumento da microflora amonificante.

PCHON et alii (1959), analisando a influência do plantio de Eucalyptus canaldulensis e Eucalyptus gomphocephala no Marrocos, verificaram que os resultados da referida implantação, foram desfavoráveis à microflora do solo. As análises (microflora total, microflora dos grupamentos fisiológicos do ciclo do nitrogênio e do carbonol mostraram uma profunda 
perturbação do equilíbrio microbiológico. Foi observada a ausência de fixa dores aeróbios de nitrogênio (Azotobacter) e de anaeröbios (Clostridium), a presença de uma microflora celulolitica aeröbia /Cytophaga principalmente, e Celluibrio) extraordinariamente ativa no liter e imediatamente abaixo, levando a uma mineralização violenta da matéria orgânica, com formação insignificante de humus, o que, segundo os autores, se deve relacionar com o desequilíbrio da microflora do solo. O pH durante os estudos oscilou entre 6 a 7.

Segundo DOMMERGUES e MANGENOT (1970), existem polifenóis que interferem na resistência de plantas e fungos parasitas, e o fenômeno de uma planta interferir no desenvolvimento de outras plantas também é ralacio nado a este fator.

CALLE e VELASCO (1972) relataram serem ainda escassas as informações sobre os processos em que atua a população microbiana na decomposição do novo liter e na biossíntese de substáncias hümicas, quando se implantam espécies resinosas sobre as antigas matas. No caso de coníferas es tes restos são ricos em polifenóis e taninos catéquicos condensados năo hidrolizáveis que, complexando as proteínas e tornando-as não utilizáveis pelos microrganismos e impregnando as membranas, retardam sua decpmposição. Por outro lado, podem também arrastar os elementos minerais verticalmente nos solos, lixiviando e acidificando o solo, e a insuficiência de bases impede a polimerização e insolubilizaçẽo destes compostos hidrolizáveis e agressivos.

Uma das características essenciais das substâncias hümicas é 
a resistência à biodegradação. Mas esta resistência não é absoluta e varỉa segundo as condições do meio, e em particular à presença de colóides argỉ D sos, DABAN (1976).

Uma vez que as comunidades microbianas do solo apresentam uma estabilidade na sua estrutura fundamental e em seu equilíbrio interno, fazendo parte integrante do ecossistema solo-planta, a troca de vegetação pro vocará alterações entre os microrganismos e a nova associação vegetal, cuja natureza interessa conhecer para poder explicar as trocas que se produzem no processo de humificação, na dinâmica do.perfil e na ciclagem de nutrỉentes, DOMMERGUES E MANGENOT (1970) e SANTOS (1977).

\subsection{Influência do $\mathrm{pH}$}

DOMMERGUES e MANGENOT (1970) consideram que a microflora influi sobre o pH do solo por intermédio dos seus produtos de metabolismo, que podem ser acidificantes (äc. minerais e orgânicos) ou alcalinizantes (por exemplo, amoníacol. A acidificação pode se dar pela produção de gás carbōnico, que é o mais abundante produto do metabolismo microbiano. Dutra maneira de acidificação pode ser pela produção de ácidos orgânicos como o för mico, acético, butírico, oxálico, succínico, que refletem a pobreza do solo em certos elementos minerais e em nitrogênio, ALEXANDER (1967). Segundo SMITH e BURNS (1965), a modificação se dá no microhabitat e o pH do solo é praticamente inalterado, a não ser que sejamimpostas alterações drásticas no ecossistema.

- pH do solo é determinado por diversos fatöres, incluindo 
concentração de saìs, gäs carbônìco na solução do solo e os cátĩons trocávels presentes. Como estes fatôres flutuam, o mesmo ocorre com o ph, a com - movỉnento da ägua através do solo, há tendência das bases serem lixiviadas e substituidas por ions hidrogênjo. Deste forma uma lixiviação constan te leva à formação de um solo ácido. Sob condições ácidas muitas substâncias se tornam mais solúveis e algumas como Ca e P. podem ser lixiviadas, resultando em deficiências nutricionajs. Aumentos na solubilização do Al. Fe, Nỉ e outros compostos, resultam que os seus níveis na solução do solo se tornam töxicos para os microrganismos e plantas, como ressaltam HOLDIMG E JEFEREY (1968).

Os fungos désenvolvem-se melhor em solos ácidos que em solos neutrons ou alcalinos. Esta predominância em solos com pH menor que 5,0 nâo é devido ao fato de que eles encontrem condições ótímas de crescimento. mas à reduçâ da concorrêncỉa de actinomicetos e bactéritus pois, estes últi mos suportam menos a acidez, DOMMERGUE'S e MANGENOT (1970).

\subsection{Aeração}

Os gases no solo encontram-se em trés estados: no estado livre nos poros do solo, dissolvidos na fase aquosa e adsorvidos na fase sóli da, CURRIE (1962). Geralmente a atmosfera do solo difere da atmosfera livre pelo aito conteúdo de $\mathrm{CO}_{2}$, SHIELDS e DURRIELL (1964). A porcentagem de ägua no solo é um fator de grande importäncia, principalmente em solos de textura fine. por apresentarem maior teor de umidade e baixa disponibili dade de oxigêní para o desenvolvimento microbiano, afetando principalmente os aeróbios obrigatórios, RHAR (1923), citado por MACLAREM e SKUJIHS (1968), 
ALEXANDER (1971), GREENWOOD (1961), GREENWOOD (1968) e ILSAROIA (1971). TEM poräria ou permanentemente, o alagamento do solo leva a carência de oxìgênio, que suprime organismos aeróbios obrigatörios, bem como a majorie dos animais e fungos, RUSSELL (1968), SHABY (s/d) e CURRIE (1962); as anaerólos que persistem, além de pouco eficientes na decomposição de resíduos, se auto inżem pela produção de äcidos rgânicos, SWABY (s/d), CURPIE (2962) e SKINER (1968)。

A atividade microbiana aumenta com o incremento da umidade até cerca de 60 a $80 \%$ da capacidade de campo, e decresce em solos saturados com ägua, SEIFERT (1960 e 1961), GONDO (1961), citados por MACLAREN e SKUJINS (1968).

A ausência de fauna em áreas áridas é um sério problema, des de que residuos orgânicos podem persistir sem se decompor durante anos. BO NEMISSA (1960), citado por SWABY $(s / d)$, sugeriu a introdução de besouros do esterco em äreas de pastagens, onde o estrume permanecia sem se decompor por värios amos, ainda que, BRTSTOL (1919) e MACLAREN e SKUJINS (1968), tenham relatado que alguns microrganismos consigam sobreviver durante periodos varỉäei em solos sêcos ao ar, inclusive bactérías não formadoras de esporos.

2.4. Toxidez

Grande nümero de elementos são tóxicos ao desenvolvimento da vegetação do solo, Do̊BEREINER e ALVAHYDO (1966), HOLDING e JERFFREY (1968), BERTRAN (1972), GRANS (1975) e MOKWUNYE (1975), D alumínio é indicado como causa principal da toxidez em solos de cerrado, e de toxidade a muitas 
plantas. A presença de alumínio no solo tende a diminuir a disponibilidade de: fósforo, cálcio, magnésio, nitrogênio, potássio e possivelmente outros elementos, GOODLAND (1971), TESAROVA (1971), MOKWUNYE (1975). O efeito ini bidor do alumínio sobre a atividade microbiana se manifesta somente nos solos ácidos, onde o conteúdo de ions $\mathrm{Al}^{+++}$trocáveis é elevado. As bactérias e actinomicetos são notadamente inibidos, os fungos são menos sensíveis, segundo YOSHIDA e SAKAY (1963), citados por DOMMERGUES e MANGENOT (1970).

As transformações de substâncias orgânicas e inorgânicas levadas a cabo pela ação dos microrganismos no solo, afetam direta e indireta mente a solubilidade e o estado do alumíniø, assim os processos microbianos de oxidação do S solubilizam quantidades consideráveis de alumínio, o mesmo pode-se dizer de ácidos nitrosos em solos de escassas bases, QUERO (1943). Um pequeno aumento na matéria orgânica leva a uma redução substancial no alu mínio trocável, possibilitando uma melhoría das colheitas quando se adiciona matéría orgânica, GRANS (1975).

No solo, o efeito depressivo indireto do alumínio sobre a atividade microbiológica se exerce pelo complemento:

- da acidificação, que vai paralela com o teor elevado de alumínio trocável, GOODLAND (1971) e GRANS (1975).

- da formação de complexos matéria orgânica-alumínio, dificilmente biodegradáveis, QUERO (1943), DOMMERGUES e MANGENOT (1970) e MOKH UNYE (1975).

- de bloqueio de certos elementos indispensáveis, TESAROVA 
(1971), GOODLAND (1971) E MOKWUNYE (1975).

A riqueza do solo em quantidades consideráveis de um elemento não deve ser considerada apesar que seus nĩveis tóxicos, como capaz de uma esterilização do solo. Em todos os solos estudados encontrou-se uma flora resistente. Isto se deve provavelmente a uma produção natural de substâncias quelantes que moderam a ação tóxica dos metais aos microrganismos, BER TRAND (1972).

\subsection{Ciclo do Carbono}

\subsubsection{Amilolise}

Segundo ALEXANDER (1967), o amido é, após a celulose, o mais comum das hexoses nas plantas, sendo a maior reserva de carbohidratos para as mesmas. O amido está presente transitoriamente nas folhas, sobretudonas dicotiledôneas, sendo acumulado nos órgãos de reserva (raízes, rizomas, tubérculos e grãos), mas também nos caules e partes aéreas. Em condições nor mais ele é mobilizado antes da morte das células. vindo ao solo em quantida des mais ou menos reduzidas. O amido é uma mistura de proporções variáveis, segundo as espécies e variedades constituintes, de amilose e amilopec tina. Os microrganismos podem também acumular amido em suas células. Ele desaparece rapidamente quando sujeito à atividade da população do solo, e sua decomposição prossegue até seu desaparecimento, e somente então, ocorre em taxas elevadas a hidrólise da celulose e hemicelulose, ALEXANDER (1965).

CHALVIGNAC (1953) afirma que a adição de amido ao solo não estimula o desenvolvimento de um microflora especial. Conclui que a degra- 
dação no solo ocorre em duas fases: primeiramente amido é convertido à dextrina e posteriormerite ocorre fermentação destas substâncias simples. BARJAC e CHALVIGNAC (1954) mostraram que a degradação do amido ocorre rapidamente em solos férteis, menos räpido em solos não férteis e vagarosamente em solos turfosos.

ALEXANDER (1961) cita que as bactérias, fungos e actinomicetos têm a capacidade de hidrolizar amido nas mais variadas condições ambien tais, e os solos frequentemente contém $10^{6}$ a $10^{7}$ ou mais microrganismos por grama de solo. Os microrganismos são particularmente mumerosos nas proximi dades das rafzes das plantas, mas a sua incidência proporcional näo ẻ signi ficantemente diferente daquéla do solo tomado a distância da planta. Hä evidências, segundo LYNCH e COINOIR (1956), citados pelo mesmo autor, de que as enzimas usadas por microrganismos na decomposição do amido, não são apreciavelmente afetadas pelas argilas.

\subsubsection{Decomposição da celulose e hemicelulose}

A decomposição da celulose tem um significado biológico espe cial no ciclo do carbono, cerca de $10 \times 10^{6}$ toneladas de carbono são fixadas anualmente na forma de celulose pela vegetação, quantidade que deverä ser decomposta no mesmo espaço de tempo. Desta maneira, uma especial atenção tem sido dada à atuação de microrganismos na degradação deste composto, DOMMERGUES \& MANGENOT (1970), REESE (1952) \& OLUTIOLA (1968)

A aptidão para degradar celulose se encontra em uma grande diversidade de microrganismos: bactérias, actinomicetos, fungos filamento- 
sos, mixomicetos, protozoärios, e nunca fol encontrada em leveduras e algas, IMSEENETSKY (1968). A ação dos fungos sobre a celulose à sem düvida menos ráplda e menos espetacular que a das mixobaotérias, porém como a sua distribulção á mais ampla e seu poder de penetraçäo mais elevado, admite-se que seu papel na natureza seja meis importante que das bactérlas, ALEXANDER (1961).

Os fatores ecológicos ma1s importantes na decomposição da ce lulose parecem ser, o potencial de óx1do redução, a estrutura e umidade, o pH. a temperatura e o teor de nitrogênio assimilável, porém com variações de intensidade de um solo para outro, IMSHENETSKY (1968), GRAY e WILLIAMS (1971), CLARK (1968) e ESCOBAR et alii (1972). O aumento da temperatura ë acompanhado de um aumento de enzimas celuloliticas, até aproximadamente $50^{\circ} \mathrm{C}$, ESCOBAR et alii (1972).

As bactérias que decompõem a celulose anaeróbicamente são principalmente aquelas formadoras de esporos. IMSHENETSKY (1968), MTSHUSTIN - MIRSOEVA (1968). A fixação de nitrogênio atmosférico por microrganismos é favorável à decomposição da celulose. Isto porque, fungos e actinomicetos celulolíticos produzem geralmente, a partir de celulose, intermediárlos solú veis que podem ser utilizados por Azotobacter. Quando Sporocytophaga e Azotobacter crescem simultâneamente em celulose, um bom crescimento de Azotobacter pode ser obtido por protocooperação com decompositores aeróbios de celulose, quando os dois säo inoculados juntos em meio apropriado, IMSHENETSXY (1968). For issc, em condições de solo, na decomposição da celulose não se acumulam glcose nem celobiose em quantidades apreciáveis, uma vez que são rapidamente utilizados como fonte de carbono também pela microflora 
secundária, que sempre acompanha a dos microrganismos degradadores da celulo se, onde também encontramos as bactérias fixadoras do nitrogênio, QUERO (1943) e IMSHENETSKY (1968).

A relação $C / N$ nos microrganismos é mais baixa que nos vegetais superiores. Portanto, quando se adiciona matéria orgânica em um solo, a microflora que a decompõe sente um deficit de nitrogênio, deficit que os microrganismos tendem a compensar, recorrendo às reservas do solo, que são geralmente pequenas, DOMMERGUES e MANGENOT (1970), GREENWOOD (1968) e ESCOBAR et alii (1972). A flutuação dos microrganismos degradadores da celulose é relacionada com a dinâmica do $N$ solúvel no solo, NAPLEKOVA (1964), citado pOr DOMMERGUES e MANGENOT (1970), BIRCH (1958), VERONA (1972), KUBISTA (197:), SZEMBER et alii (1972) e TODOROVA e BENEVSKY (1971). A forma de nitrogênio incorporado ao solo é um fator que afeta marcadamente a decomposição da celulose. Nitrogênio orgânico ou míneral adicionado leva a um aumento da microflora anaeróbie e aeróbia, respectivamente, TESAROVA (1971). A presença de nitrogênio, principalmente na forma amoniacal, facilita a decomposição da celulose em solos neutros e alcalinos, QUERO (1943) e CLARK (1968).

Um outro fator limitante à celulolise parece ser a deficiência de fósforo, e o nitrogênio o é para toda a decomposição de material orgânico, KONG e DOMRERGUES (1973a), KONG e DOMMERGUES (1973b). A degradação da celulose parece ser também influenciada por outros grupamentos funcionais, BAREA (1970) e KONG e DOMMERGUES (1972).

O ótimo de umidade para a decomposição da celulose é cerca 
de $60 \%$ da capacidade de campo, entretanto, fungos e bactérias podem iniciar a decomposição da celulose em umidades baixas, FEHER (1946), citado por IMSHENETSKY (1968). O autor relata ainda a presença de bactérías celuloliticas em arelas do Saara, onde virtualmente não chove. NOVOGRADSKY (1946), citado pelo mesmo autor, observou Penicillium crescendo em solos onde a umidade era cerca de $3,3 \%$. A temperatura onde ocorre celulolise pode variar de $15^{\circ} \mathrm{C}$ até $65^{\circ} \mathrm{C}$, BONISCHOVA et alii (1970) e DOMMERGUES e MANGENOT (1970). Os que agem em temperaturas altas são os termófilos, como a maior parte dos Clostridium anaeróbios para os quais o crescimento é escasso abalxo de $50^{\circ} \mathrm{C}$ s são considerados também como termófilos os actinomicetos Streptomyces, Micromonospora, e os fungos dos gêneros Chaetomium e Humicola, porém eles podem agir como mesófilos, crescendo em temperaturas de $20^{\circ} \mathrm{C}$, segundo COONEY e EMERSON (1964), citados por DOMMERGUES e MANGENOT (1970). Mas os celulolfticos do solo são em sua grande maioria mesófilos, com exigências muito varáveis, segundo as espécies ou raças, ALEXANDER (1967) e BONISCHOVA et alii (1970).

BASU e GHOSE (1960) notaram que a produção de celulase por fungos é estimulada pela presença de hemicelulose. O têrmo hemicelulose designa um conjunto heterogêneo de substânclas variáveis segundo as espécies e as variedades, difíceis de analisar quimicamente. Análises de materiais vegetais mostraram que a hemicelulose pode constituir uma fraçãoimportante da ma téria orgânica. Assim, os xilanos que são os glucídios secundários mais abun dantes na natureza, representam 15 a $30 \%$ nas palhas, 20 a $25 \%$ na madeira das dicotiledôneas e 7 a $12 \%$ na madeira das coniferas, DOMMERGUES e MANGENOT (1970). GRAY e WILLIAMS (1971) evidenciam que as hemiceluloses ocorrem nas paredes espessas das células, nos troncos, raízes, folhas e sementes de 
plantas. Elas sâo de dois tipos distintos, poliuronöides, que consiste de repetidas unidades de açücares e ácido urônico, e celulosanas, que consiste somente de açúcares. Quimicamente, elas não são relacionadas com a celulose pelo seu conteúdo com 5 carbonos açúcares e 6 carbonos açúcares, por exemplo, xilose, arabinose, galactose e manose. Entre os tipos mais comuns estão as pectinas, pentosanos, mananos, xilanos e galactanos.

A taxa de himicelulose diminui rapidamente nos restos vegetais colocados no solo, quando se compara com celulose. No período de três meses, segundo SCHOBINGER (1968), citado por DOMMERGUES e MANGENOT (1970), no caso de palha inoculada com solução de solo, 95\% de holocelulose (celulose + hemicelulosel foram destruidos, enquanto que para a celulose sozinha, as per das atingiram 96 a $98 \%$. Isto parece indicar que existe um perfodo de decompos1ção bastante at1va segu1da de uma nit1da dIm1nu1ção. Se por exemplo, $60 \%$ das pantosanas são decompostas em dois meses, precisamos de quatro anos para que elas sejam decompostas inteiramente. Assim. o nível de hemicelulose tende a se estabilizar nas condições naturais, e pode mesmo, posteriormen te, ser elevado em pequena quantidade, de modo que nos solos orgânicos ele se estabiliza entre 10 e $15 \%$. Estes fatos podem ter duas explicações, que não se excluem as diferentes substâncias classificadas entre as hemiceluloses e que são desigualmente lábeis: os xilanos e mananos são frägeis e desaparecem primeiro, enquanto o galactanos parecem mais resistentes, mesmo "in vitro". A decomposição de xilanos purificados torna-se extremamente lenta após algum tempo, segundo SORENSEN (1957), citado por DOMMERGUES e MANGENOT (1970). 
são degradadas, a microflora sintetiza outras substâncias pertencentes à mes ma categoria: glucanos e pentosanos das membranas esqueléticas dos fungos filamentosos, mananos das leveduras e glucanos e levanos das cápsulas bacterianas, ALEXANDER (1967). Consequentemente, ocorre o enriquecimento em áci urônicos que certos autores observaram no solo, mas a sua dosagem em material complexo é difícil, segundo DEVEL et alii (1960), citados por DOMMERGUES e MANGENOT (1970). A atividade hemicelulolítica é mais amplamente distribuida que a atividade celulolítica, embora em geral, a hemicelulolise se desenvolva paralelamente à celulolise, ocorrendo em intensidades diferentes mesmo que fatôres externos exerçam efeitos semelhantes nos dois fenômenos, ALEXANDER (1967), GRAY e WILLIAMS (1971) e BACON (1968). A decomposição das hemiceluloses é diminuida em anaerobiose. Os fungos desempenham o papel prin cipal em meio ácido e travam concorrência com as bactérias nos solos neutros. A temperatura ótima para ação das xillanases é de $37^{\circ} \mathrm{C}$ com tendência termófila dos actinomicetos, que preferem 45 a $50^{\circ} \mathrm{C}$, DOMMERGUES e MANGENOT (1970).

Como na celulolise, a decomposição da hemicelulose está na dependência de um teor suficiente de nitrogênio. Em palhas enriquecidas em nitrogênio e sais minerais, as hemiceluloses são degradadas cinco vêzes mais rápido que no mesmo produto não enriquecido. Os tecidos jovens são atacados mais rapidamente que os velhos pois, a natureza das hemiceluloses modifica com a idade, pelo seu estado físico transformado ou pelo estabelecimento de ligações com outros componentes da parede. Assim, no caso da madeira, as pentosanas livres são atacadas primeiro, a seguir a degradação das hemiceluloses progride paralelamente aquela da celulose, qualquer que seja o tipo de 
podridão, DOMMERGUES e MANGENOT (1970).

\subsection{Ciclo do Nitrogênio}

Nitrogênio, fósforo e potássio são os principais nutrientes das plantas, derivados do solo, e daí a importância que assume a disponibili dade biológica destes elementos. O nitrogênio é o mais dependente das trans formações microbianas, ao passo que o carbono é reciclado com liberação de $\mathrm{CO}_{2}$ para a atmosfera, o nitrogênio tem ponto crítico na transformação de $\mathrm{N}$ gasoso e do $\mathrm{N}$ dos resíduos vegetais e animais, em formas assimiláveis pelas plantas superiores, ALEXANDER (1961) e CLARK (1968). O nitrogênio é o elemento chave da molécula das proteínas, base de toda a vida. Sua deficdência reduz marcadamente a produção agrícola, em quantidade e qualidade. Sua disponibilidade no solo é matéria de constante preocupação, especialmente devido ao fato que ë um dos poucos nutrientes do solo perdido por volatiliza ção e lixiviação, FREIRE (1975), DELWICHE e BRYAN (1976) e GREENWOOD (1968).

O nitrogènio pode ser incorporado ao solo de várias maneiras: ägua de chuva, fixação não simbiótica, fixação simbiótica, fertilizantes nitrogenados (orgânicos e inorgânicos). A maior parte dos nitrogenados do so10, ou a eles adicionados, está na forma orgânica não assimilável, além disso, uma parte do $\mathrm{N}$ mineral encontra-se numa forma não trocável, "amonia fixa da" nos minerais argilosos. A mobilização e a liberação do elemento é essen cial portanto, para a fertilidade do solo, ALEXANDER (1961), DOMMERGUES e MANGENOT (1970) e BACON (1968).

A mineralização do $\mathrm{N}$ é análoga à liberação do $\mathrm{CO}_{2}$ dos mate- 
riais carbonados, pelo fato de ambos os processos resultarem em formas inorgânicas, e de constituirem os únicos meios de regenerarem os nutrientes em forma utilizável pelos vegetais verdes. Pela mineralização, o nitrogênio or gânico desaparece e acumula-se amônia e nitrato em duas fases distintas, amo nificação e nitrificação, ALEXANDER (1961), DOMMERGUES e MANGENOT (1970) e SWABY $(s / a)$.

\subsubsection{Amonificação}

A amônia é tipicamante um subproduto do metabolismo microbiano, cujo acúmulo representa a sobra da demanda de nitrogênio do desenvolvimento de vasta parte da microflora. Estimativas da população de amonificantes em diversos solos, revelam aproximadamente $10^{5}$ a $10^{7}$ organismos por grama de solo, o que, entretanto, é altamente variável com o substrato adiciona do, ALEXANDER (1961).

Quase todas as bactérias, fungos e actinomicetos atacam algum composto de nitrogênio, sendo variável a rapidez e os compostos utilizados, de acôrdo com os gêneros e espécies envolvidas. A diversidade fisiológica dessa flora faz com que o nitrogēnio seja mineralizado nas mais extremas condições, ALEXANDER (1961) e BACON (1968). A adição de proteínas ao so lo favorece o desenvolvimento das bactérias Bacillus, Pseudomonas, assim como de Clostridium, Serratia e Micrococcus, HIRIE (1972). Muitos fungos decompõem proteínas, aminoácidos e outros nitrogenados como fonte de carbono e ni trogênio, sendo que os aminoácidos também podem ser fontes de enxofre. A liberação de amônia é frequentemente menor do que a resultante da decomposição pelas bactérias pois, mais $N$ é usado na síntese celular. Sem dúvida, os 
fungos predominam na proteólise em certos solos, especialmente em ambientes ácidos. Após a degradação inicial pelos proteolíticos, outros organismos apa recem utilizando os produtos metabólicos dos primeiros. A produção de $\mathrm{N}$ inorgânico é maior em solos neutros, entretanto, a acidez deprime, mas não altera a produção, ALEXANDER (1961), BIEDERBECK e CAMPBELL (1973).

A umidade, pH, aeração, temperatura e suprimento de nutrientes inorgânicos governam a velocidade de mineralização, além de existir o efeito benéfico da argila e lignina, ALEXANDER (1961), DOMMERGUES e MANGENOT (1970) e CAMPBELL e BIEDERBECK (1972). Melhor mineralização ocorre em temperaturas próximas dos $35^{\circ} \mathrm{C}$, STANFORD e SCHWANINGER (1973).

A uréia, além de fertilizante químico, ocorre no solo pela decomposição dos ácidos nucleicos, e nos excrementos dos animais, o que lhe dá grande importância. Bactérias, fungos e actinomicetos sintetizam urease e portanto, podem utilizar uréia como fonte de N. Em geral, a degradação da uréia é realizada mais ativamente em condições aeróbias, ALEXANDER (1961) e ROSS e BRIDGER (1977), e uma maior mineralização foi observada por ROSS e BRIDGER (1977), ocorrendo a uma profundidade de $0-4 \mathrm{~cm}$ que de $0-8 \mathrm{~cm}$. A adi ção de proteínas de origem animal ou vegetal não é estimulante para todas as espécies proteolíticas "in vitro", mas apenas eles são capazes de competir pelo substrato neste ambiente. A adição de substâncias naturais altamente nitrogenadas, como os alimentos vegetais, caseína hidrolizada e uréia, tem sido usadas para estudos de fatôres que controlam a amonificação, e como enriquecimento para amonificantes, POCHON (1968). A adição de $\mathrm{NH}_{4}$ aumenta o número de bactérias e actinomicetos, mas não influi significativamente no nü mero de fungos, BIEDERBECK e CAMPBELL (1973). 


\subsubsection{Nitrificação}

A mineralização do N termina com a formação de amônia, forma mais reduzida do $\mathrm{N}$ inorgânico. E o ponto de partida para o processo de nitrificação, ou seja, formação biológica de nitrito e nitrato, ALEXANDER (1961), DOMMERGUES e MANGENOT (1970) e CLARK (1968).

A importância dos microrganismos nitrificantes está na capacidade de produzir nitrato, a maior fonte de $N$ para as plantas superiores, GRAY e WILLIAMS (1971). A nitrificação biológica tem sido também usada como indicadora da fertilidade de solos, e um bom crescimento de plantas é consideravelmente dependente da transformação, CHASE, CORKE e ROBINSON (1968). Os autores ainda consideram a sugestão de vários pesquisadores a cerca da assimilação preferencial de amônia pelas coníferas, e de nitratos pelas decíduas.

A proporção de $\mathrm{NH}_{4}$ convertido em $\mathrm{NO}_{3}$ tende a decrescer com a profundidade e com o decréscimo da temperatura de incubação do solo, ROSS e BRIDGER (1977). D pH também exerce uma grande influência na nitrificação. Em ambientes ácidos a marcha é lenta, mesmo com o aumento de $\mathrm{NH}_{4}$, estando o pH ótimo em tôrno de 7,8, THEOBALDI e SMITH (1974), CALLE e VELASCO (1972), WEBER e GAINER (1962), CHASE, CORKE ROBINSON (1968), ALEXANDER (1961) e ALEXANDER (1968). Sendo alcalina, a amônia inicialmente eleva o pH do solo, na faixa de aplicação, tendo-se constatado valores de até 9,5 , SMILEY $e$ PAPENDICK (1967) e KIEHL e ROCHA FILHO (1972). Uma vez iniciada a nitrificação, o pH sofre um decréscimo que leva a uma forte acidificação local, KIEHL e ROCHA FILHO (1972), sem contudo alterar substancialmente a relação 
do solo como um todo. Solos de textura arenosa apresentam maior variação de $\mathrm{pH}$, devido o seu baixo poder tamponante, KIEHL e COBRA NETTO (1976).

o oxigênio é um fator limitante na nitrificação, que cessaem condições de ausência de $\mathrm{O}_{2}$. Assim, a estrutura do solo afeta o acúmulo de nitrato; a umidade do solo afeta especialmente pela relação com a aeração pois, o encharcamento limita a difusão de $0_{2}$, GRAY e WILLIAMS (1971),BRANDT, WOLCOTT e ERICKSON (1964), GREENWOOD (1968), ROSS e BRIDGER (1977), CAMPBELL e BIEDERBECK (1972) e STANFORD e SCHWANINGER (1973). : Por outro lado, é citado que em pressões normalmente elevadas de $0_{2}$, a produção de nitratos é também baixa, DOMMERGUES e MANGENOT (1970), CARK (1968) e GREENWOOD (1962).

A adição de fosfato pode aumentar a taxa de proliferação de bactérias nitrificantes, CHASE, CORKE e ROBINSON (1968), sugerindo que em solos deficientes em fósforo, a população de nitrificantes pode ser baixa pela limitação de fosfatos.

o tipo de cobertura vegetal afeta o número e a atividade de microrganismos nitrificantes. Com muitas culturas não há preferência, entretanto, uma mesma espécie tem influência variável conforme o solo. Raf́zes de Pinus (Pinus spp) em solos ácidos possuem baixa atividade de nitrato redutase, e esta atividade depende do nível de $\mathrm{NO}_{3}$ e pH da solução nutriente, THEOBALDI e SMITH (1974) e RUSSELL(1968). A nitrificação tem lugar entre 5 e $45^{\circ} \mathrm{C}$, sendo muito lenta fora destes limites, estando o seu ótimo si tuado entre 30 e $35^{\circ} \mathrm{C}$, ALEXANDER (1961). Há evidências que a nitrificação é proporcional à capacidade de troca de cátions. Ela tem lugar na pelf́cula de água que envolve as partículas do solo, ALEXANDER (1961) e RUSSELL (1968). 
Nitrosomonas e Nitrobacter são autótrofos obrigatórios, CHASE, CORKE e ROBINSON (1968), e sem estágio heterótrofo em seu ciclo de vida, utilizam somente $\mathrm{CO}_{2}$ e carbonatos como fonte de carbono, DOMMERGUES e MANGENOT (1970). Em geral, Nithosomonas e Nitrobacter são achadas juntas, se assim não fôsse. os nitritos se acumulariam a níveis tóxicos para as plantas e microrganismos, BERTRAND (1972), DOMMERGUES e MANGENOT (1970). Ni trobacter ë citada como sendo mais sensível à condições adversas como baixas e altas temperaturas, e secas, do que Nitrosomonas, JUSTICE e SMITH $(196 \Omega)$.

A evidência de que a oxidação da amônia excede as quantidades de nitritos formados fói confirmada em alguns casos; na natureza, em so los neutros ou alcalinos, toda a amônia oxidada é recobrada como nitrito ou nitrato, ALEXANLER (1961) e HEILMAN (1974).

- incremento da tensão osmótica e da concentração salina são apontados como causadoras do decréscimo na nitrificação, embora a atividade microbiana total seja pouco afetada, JOHSNSON e GUENZI (s/a). A adição de glucose e caseína hidrolizada ao solo e em meios de cultura inibe a nitrifí cação. Esta inibição não é causada pela toxidez direta desta adição, mas provavelmente resulta de um efeito estimulador em organismos heterotróficos, e o aumento da amônia seria produto de seus meatabolismos, THEOBALDI e SMITH (1974). Isto se deve, provavelmente, à sensibilidade de Nitrobacter aos sais de amônia em ambientes alcalinos, RUSSELL(1968) e STOJANOVIC e ALEXANDER (1958).

HEILMAM (1974) explica que a baixa capacidade de nitrifica- 
ção de alguns solos resulta primarlamente da balxa população de organismos nitrificantes, e que o aumento do nivel de nitrato, resultante do tratamento com uréla, está relacionado com o crescimento da população de organismos nitrificantes, em resposta à adição de nitrogênio amoniacal. ROBINSON (1963) mostrou que algumas granlneas removem rapldamente lons amônia do solo, portanto competindo diretamente com bactérias nitrificantes do solo. E conhec1do alnda que diversas plantas, Incluindo gramíneas e flores de verão, pro duzem substânclas antimlcroblanas, como ácldo clorogênico e taninos, que su primem a nitrificação, BOUGHY et alii (1964), RICE (1965) e STIVEN (1952). WELCH e SCOTT (1960) c1tam que bentonita e 1lita flxam a amônia, que é nitrificada vagarosamente. A adição de $K^{*}$ pode também reduzir o processo.

A habilidade em produzir nitrito em pequenas quantidades ë ralativamente frequente entre bactérlas e actinomicetos, e frequentemente es te nitrito desaparece através de assimilação, especialmente porque a demanda de nitrogênio é grande, devido a níveis excessivos de carbono. A nitriflcação por organismos heterotróficos é hoje um fato comprovado. Existe Uma dificuldade em seu isolamento, pois não podem ser 1solados por enriqueclmento preferencial, já que outros heterotróficos serão também estimulados no meio com substratos orgànicos, CUTLER e WUKSRRJ, citados por ALEXANDER (1961). A evidência presente é de que os heterotroficos sejam de reduzida responsabilidade na produção de nitritos e nitratos no solo, podendo porém se destacar em ambinetes atíp1cos, ALEXANDER (1961). Segundo CROCOMO (1967), a nitrificação heterotrófica foi observada em fungos por SCHMTDT (1954) em Aspergillus flavus e por MALAVOLTA et alii (1955) em Aspergillus wentii. Esta oxidação de $\mathrm{NH}_{4}^{+}$a $\mathrm{NO}_{3}^{-}$heterotroficamente pode ser seguida ma- 
nométricamente e quimicamente. A formação de $\mathrm{NO}_{2}^{-}$a partir de $\mathrm{NH}_{4}^{+}$é de ocorrereñcia mais geral que a nitrificação. Tem-se sugerido que a enzima peroxidase está comprometida nessa oxidação. ARZOLLA (1959), trabalhando com Aspergillus wentii whermam, observou que o ótimo de temperatura para o desenvolvimento do fungo, e da nitrificação heterotrófica, estava entre 25 e $35^{\circ} \mathrm{C}$.

Propõe-se que o têrmo nitrificação seja definida como: a conversăa de nitrogênio em compostos orgânicos ou inorgânicos a partir de uma forma mais reduzida para uma mais oxidada, NICHOLAS (1963), citado por CROCOMO (1967).

\subsubsection{Denitrificação}

O trabalho dos microrganismos no solo, transformando o nitro gênio orgânico em inorgânico, imobilizando-o outra vez em forma não disponí vel, ou oxidando-o pela nitrificação, leva muitas vêzes à perda pela ocorrência de certas transformações que conduzem à volatilização, isto é, N gaSOSO, DELWICHE e BRYAN (1976), YUFERA e DORRIEN (1973) e SKINER (1968). Es ta perda tem efeito maléfico com respeito à produção vegetal, pois diminui a reserva de nitrogênio no solo, e é ocasionada pela redução do nitrato, e liberação do $\mathrm{N}$ molecular ou óxido nitroso, ALEXANDER (1961) e DOMMERGUES e MANGENOT (1970). Cerca de $1 / 3$ do $N$ aplicado como fertilizante no solo pode ser perdito por denitrificação, SMITH (1977). A aplicação de $\mathrm{N}$ em formas de mais lenta transformação, como compostos de formaldeido de uréia, tem sido usados para diminuir as perdas de nitrogênio, KOIKE (1961) e YUEERA $e$ 
DORRIEN (1973).

A denitrificação pode ser biológica ou química, DELWICHE e BRYAN (1976). Na denitrificação biológica, o nitrogênio é volatizado para a atmosfera através do mecanismo respiratório de certos microganismos, ou da utilização do nitrato ou nitrito para o seu desenvolvimento, o que aeria uma assimilação, CADY e BARTOLOMEU (1960), citados por ALEXANDER (1961). A verdadeira denitrificação é limitada a certas bactérias; fungos e actinomicetos não são implicados. Contudo, qualquer organismo que cause mudança no pH em meio de cultura, suficiente para permitir volatilização da amônia, de composição de nitritos, ou reação não enzimática de amônia ou aminados com nitritos, será causa de perda gasosa. Este fato tem sido observado em labo ratório. Entre os fatôres que influenciam a denitrificação estão: nível de $\mathrm{O}_{2}$, $\mathrm{PH}$, fatôres de crescimento e temperatura, DELWICHE e BRYAN (1976) e GREENWOOD (1968). Dutros fatôres são também apontados como influencladores: vegetação, natureza e quantidade de matéria orgânica, ALEXANDER (1961) e DOMMERGUES E MANGENOT (1970).

o oxigênio afeta de duas formas a denitrificação, de um lado há denitrificação quando $\mathrm{O}_{2}$ é insuficiente à demanda microbiológica, ao mes mo tempo $\mathrm{O}_{2}$ é necessário para produção de nitratos e nitritos, os quais são essenciais para a denitrificação, ALEXANDER (1961). A denitrificação é tida como ocorrendo apenas em condições anaeróbicas, ALEXANDER (1961), SKINER (1968), DELWICHE e BRYAN (1976), embora este fato seja atualmente sujeito. a sérias controvérsias, BOLLAG, ORCUTT e BOLLAG (1970), DELWICHE e BRYAN (1976) e SKINER (1968). Se não há adição de nitratos, deve haver microambientes aeróbios para os nitrificadores, e sitios anaeróbios para os deni- 
trificadores, ou durante perfodos chuvosos intermitentes, formação de nitra tos e redução posterior BREMER e SHAW, citados por GREENWOOD (1968), LOEWENSTEIN et alii (1957). Similarmente, denitrificação poderá ocorrer em so los de arrozais recebendo sais amoniacais pois, a amônia é oxidada na zona superior de penetração do $O_{2}$ e a lixiviação do nitrato formado leva-o para a zona anaeróbia inferior, ALEXANDER (1961). A denitrificação é desta forma relacionada diretamente com a umidade, devido ao fator de difusão do 0, DELWICHE (1956) citado por SKINER (1968), ALEXANDER (1961), DOMMERGUES e MANGENOT (1970), YUFERA E DORRIEN (1973) e SMITH (1977).

A denitrificação é um processo neutrófilo, pois seu pH se si tua entre 7,0 e 8,6, DOMMERGUES e MANGENOT (1970), e é inibida em altas con centrações de hidrogènio. O pH do solo influi não somente sobre a quantida de total de produtos gasosos formados, mas também na sua proporção relatiVa, BOWMAN E FOCHT (1974), DOMMERGUES E MANGENOT (1970), DELWICHE e BRYAN (1976) e THEOBALDI e SMITH (1974). Próximo de $\mathrm{pH} 7,0$ algum $\mathrm{N}_{2} \mathrm{O}$ à formado, mas ele é pouco reabsorvido, obtendo-se boa denitrificação. Esta reação ë aparentemente afetada por condições ácidas, NO é produzido a baixos niveis entre $\mathrm{pH} 6,0$ e 7,0, mas sob condições mais ácidas, NO é produzido em altos nLveis. Aproximadamente $20 \%$ do nitrogènio envolvido a pH 5,0 à perdido em temperaturas próximas dos $30^{\circ} \mathrm{C}$, geralmente, mas não sempre, favorece os denitrificadores, DELWICHE e BRYAN (1976). Para BREMER e SHAW (1958), citados pelos mesmos autores anteriores, o ótimo de temperatura para a denitrificação situa-se entre 60 e $65^{\circ} \mathrm{C}$, mas altas temperaturas usualmente citadas, são provavelmente resultantes de reações não biológicas, DELWICHE e BRYAN (1976) E SKINER (1968). 
o cultivo reduz a denitrificação, devido à assimilação pelas plantas de $\mathrm{NO}_{3}^{-}$disponível, ALEXANDER (1961), ao passo que a denitrificação pode ser estimulada pela adição de substãncias doadoras de elétrons ao nível da rizosfera, ou por intermédio de resíduos aéreos (liter) ou subterrâ neos (raizes), DOMMERGUES e MANGENOT (1970). A relação C/N em tôrno de 2 mostrou-se boa para promover alta taxa de denitrificação. Taxas altas de relação C/N ou alta concentração de glicose, retarda a denitrificação, com o crescimento de fungos e subsequente queda po $\mathrm{pH}$, BOWMAN e FOCHT (1974).

A extensão em que as reações não biológicas contribuem para a denitrificação observada é de difícil avaliação. A conversão de ions ni tritos em produtos gasosos em condições estéreis é geralmente favorecida pe lo ion higrogênio mas, mesmo a pH 7,0, apreciável reação pode ser observada, DELWICHE e BRYAN (1976), CLARK, BEARD e SMITH (1960), citados por ALEXANDER (1961).

\subsubsection{Fixação do nitrogênio}

A fixação do $N$ pode ser de natureza biológica (fixadores sim biontes e fixadores de vida livres ou através de meteoritos, adsorção de amônia atmosférica ou processos industriais; DOMMERGUES e MANGENOT (1970) e EAHRAEUS e LJUNGGREN (1968). O nitrogênio é um dos elementos mais importan tes à vida como a conhecemos. E o material essencial na construção das pro teĩnas e outras moléculas da célula viva. Entretanto, apesar de sua abundância na atmosféra, ele é pouco disponível pois, pode ser incorporado na maioria dos sistemas de vida, através de suas formas "fixadas", isto é, com binado com outros elementos. No ar atmosférico, o nitrogênio existe prin- 
cipalmente na forma diatônica de gás $\left(N_{2}\right)$ inerte, para que ele se combine a outros elementos ou substâncias, uma ou outra forma de energia é imprescindível, ALEXANDER (1961).

Os organismos clássicos fixadores de vida livre são espécies de Azotobacter, Clostridium e muitas algas verde azuladas. Mas muitos gêne ros de microrganismos foram descritos como fixadores, ALEXANDER (1961) e DOMMERGUES \& MANGENOT (1970). Para D\&BEREINER (1977), os cerrados brasilei ros constituem uma área promissora à implantação de sistemas agrícolas econômicamente viáveis, onde estudos sobre a fixação biológica do mitrogênio são fundamentais. Autores como PERES et alii (1977) e SILVA (1977) têm constatado entre as dificuldades para o uso eficiente dos cerrados, a sua pequena capacidade em reter potássio e nitrogênio.

Uma série de fatôres restrịnge a fixação do nitrogênio pelos microrganismos não simbióticos, entre eles: necessidade de produtos energéticos (carbohidratos necessários para o processo), luminosidade (fator essencial para os organismos fototróficos), condições ambientais desfavoráveis, principalmente temperatura, pH baixos e teores tóxicos de elementos, como o alumínio no solo, ALEXANDER (1961). Clostridium é mais tolerante à concetrações de $H$ que os outros fixadores, DOMMERGUES e MANGENOT (1970) e ALEXANDER (1961)。

Segundo DOMMERGUES e MANGENOT (1970), o fósforo estimula notadamente a fixação de $N$, este estímulo é reduzido na presença de potássio, e muitos nutrientes inorgânicos são necessários ao metabolismo do $N_{2}$, molib dênio, cálcio e ferro, são elementos críticos para as reações de fixação, 
ALEXANDER (1961). O pH exerce ume grande influéncìa na microflora fixadora, tendo VELASCO e CALIE (a/d) relatado que em locais onde a eltitude e a acidez aumentavam, os solos tornavam-se Azotobacter negativos, ombora se tor nassem favorävełs a desenvolvimento de fixadores anceröbios. A fixaçẽo nä́ simbiötica de maneira geral desenvolve-se melhor em pH próximo ao neutro. condição que dificilmente ocorre em solos sob liter de conlferas. Espécies de Beijerinckia crescem em pHácidos, chegando mesmo a orescer em pH 3,0, Clostridium tem uma exigêncie intermediáría, ou seje. pH 5,0. Certas espë cies de Pseudomonas são responsäveis vela fixação de nitrogênio em solos florestais ácidos, DOMMERGUES e MANGENOT (1970).

\section{DARBYHIRE (1964), citado por FAHRAEUS E LeTUNGGPEN}

notou que duas espécies de Rhizobím estudadas eram retardadas na nodulação pela adição de nitrato e nitrito, embore isto não fosse constante pela adição de amônia. BeJALFVE (1962) observou que Rhizobium pode agìr como estimu lador de fixação de nitrogênio em Nostoc.

A incidéncia e efetividade de bactérias fixadoras de nitrogê nio tem sido estudadas em muitos outros solos, e alguns resultados indicam que há uma correlação entre a cultura e o organísmo ativo, tendo DỏBEREINER (1959) verificado influência favorável da vegetação de cana-de-açúcar sobre bactërias fixadoras do $N$ atmosférico, em especial Beijerinckia DERX. Segundo a autora, tais bactérias usando exsudatos das raízes como alimento, fi xam o $N$ atmosférico que é aproveitado pelas plantas as quais se associam. 0 enriquecimentonitrogenado dos solos pelo emprego de fixadores de vida livre tem sido extensivamente explorado. E de interesse o estudo feito por TABOA $D A$ et alii (1973) que verificaram a capacidade da bactëria Aghobacterium 
azotophilum de fixar o nitrogênio no solo, tanto em aerobiose como anaerobio se, usando fontes de carbono variadas como massa de milho a sub-produtos da indüstria açucareira. ASCENCAOO et ali讠 (1977) ao testarem o poder ie sowe vivênciade Derxía gummosa e SpiriRlum lipoferum am solos de cerrado, verifi caram que solos autoclavados tiveram efeito drạstico na diminuição de taís bactérlas e a adição de fertilizantes promoveu um aumento na sobrevivência. Vários trabalhos afirmam que a introdução de Azotabacter eumentou o $N$ do so 10 pela fixação do mesmo, BROWN, JACKSON e BUNNINGHAN (1968). MISHUTIN e NAUMOVA (1962), citados pelos autores acima, em um trabalho utilizando ${ }^{15} \mathrm{~N}$. mostraram que não houve uma grande fixação em rizosfera de trigo inoculada $\operatorname{com} 10^{6}$ talos bacterianos de Azotobacter por grama de solo, quanto comparada com a rizosfera não inoculada.

\subsection{Fösforo}

o fósforo é um elemento essencial, entrando na constituição de todas as células vivas, e está implicado na construção de moléculas orgâ nicas, na síntese de material genético, e nos processos de acúmulo e transferência de energia. ALEXANDER (1961) e HODSON (1973).

No solo ele pode se apresentar na forma orgänica ou mineral. As formas orgânicas provêm de resíduos vegetais e animais, assim como das células microbianas, às principajs formas orgânicas são: fitina, nucleoproteínas, ácidos nucleicos, fosfolipídios e açúcares fosforilados, e represen tam de 15 a 80\% do fósforo total do solo. PEARSON (1941), citado por HODSON (1973), DOMMERGUES e MANGENOT (1970). Na forma mineral pode apresentar-se nas seguintes formas: ions $\mathrm{PO}_{\ell} \overline{\bar{Q}}$ de solução dp solo, formas assimiladas por 
desabsroção, que são os ions $\mathrm{PO}_{A} \equiv$ adsorvidos às superfícies dos colóides do solo por intermédio dos cátions $\mathrm{Ca}^{+^{+}}$, $\mathrm{Fe}^{+++}$, $\mathrm{Al}^{+++}$, e nas formas nẫo assimiláveis tais como: fosfato tricálcico $\left.\left(\mathrm{CPO}_{4}\right)_{2} \mathrm{Ca}_{3}\right)_{3}$ hidroxi-apatìte $\left(3\left(\mathrm{PO}_{4}\right)_{2}\right.$

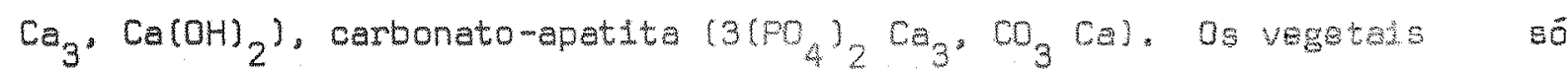
absorvem o fósforo na forma de ions $p_{4} \equiv$, que provem de solubilizacão de formas minerais insolúveis ou pela mineralizeçäo de formas orgânicas. Os microrganismos telüricos atuam na disponibilidade do fósforo de värias formas: solubilização de compostos inorgânicos do fósforo, minerallzação de compostos orgânicos, imobilização de anions inorgânỉcos disponiveỉs pela conversåo em constituintes do protoplasma microbiano, e pela oxidação ou redução dos compostos orgânicos do solo. ALEXANDER (1961) e DOMMERGUES \& MANGENOT (1970).

A solubilização biológica do fósforo ë um fato comprovado, ASKINAZI (1958), TAHA et alii (1969), HODSON (1973) e MADAN (1974), A ori gem biológica da solubilização dos fosfatos insolúveis decorre assim de um estímulo da microflora telürica, levando a um aumento do fósforo assimilável. Este estímulo da microflora é induzido, não somente por um aparte da matéria orgânica, mas também como evidenciou TARDIEUX e ROCHE (1966), citados por DOMMERGUES e MANGENOT (1970), pela incorporação de fosfatos naturais e insolúveis. Is fosfatos naturais são usados como forma de adubação, porém respostas das culturas a esta adição são variáveis e dependem de värios fatôres, tais como: biológicos, ambientais e edäficos, CARVAJHO et alii (1969). Os microrganismos responsäveis pela solubilizaçäo pertencem a diversas espécies e são relativamente abundantes no solo, EIRA e CARVALHO (1970), DOMMERGUES e MANGENOT (1970), HODSORT (1973), e odem representar uma 
fração abundante da população, 10 a 15\%, SPERBER (1958), SWABY e SPERBER (1958), KATSNELSON et alii (1962), ou porcentagens ainda maiores de eté 95\% em certos solos, KUBUS (1962), citado por DOMMERGUES E MAMGEMOT (1970). TARDIEUX \& ROCHE (1966), citados POI DOMMERGUES e MANGENOT (1970), enumeraram algumas bactërias ativas na solubilização, espécles de Pseudomonas, Alcaligens, Achromobacter. Agrobacterum, Aerobacter, Escherichia, Brevibacterium, Micrococcus, Flavobacterium e certos actinomicetos e fungos como Penicillium, Aspengillus, Rhizopus, Sclerotium são também solubilizadores. ASKINAZI (1958) isolou do solo, vinte e cinco espécies de wac térias, das quais doze tinham açấo solvente sobre fosfatos de rocha e fosfa tos bi e tricálcicos, JAYARAMAN e PRASAD (1972), estudando a produção de fosfatase em Aspergillus isolados do solo, constataram que Iinhagens de A. niger, foram mais ativas na produção desta enzIma. Resultado seme Ihante havia sido obtido por CARVALHO et alii (1969) em experimentos onde foi avaIiada quantitativamente a solubilização de fosfatos por espécies dos gêneros de Penicillium e Aspengillus, onde A. niger solubilizou quantidades apre ciäveis de fosfatos. EIRA e CARVALHO (1970), estudaram a solubilizaçäo de 8 fosfatos insolúveis: fosfato tricálcio, fosfato bicálcío, escoria de Thomas, hiperfosfato, fosforita de Olinda, apatita de Araxá, fosfato de ferro e fosfato de alumínio. Os microrganismos usados no trabalho foram isolados de raỉzes e rizosfera de cana-de-açücar de quatro grandes grupos de solos do Estado de São Paulo. Também A. niger mostrou uma melhor solubilização, seguido de algumas espécies de Penicillium, Aspengillus, Thichoderma, Fusidium e Fusarium. Foram isoladas também duas linhagens Thielavia terricola e os gêneros Stachybotrys e Cunninghamela, que ainda não haviam sido descrí. 
tos como solubilizadores.

Em solos ácidos o fósforo da solução do solo é fixado por pre cipitação em forma de fosfato de ferro e de alumínio, formando a fração não não trocável de fósforo do solo, EIRA e CARVALHO (1970), IESAROVA (19?1), YUFERA e DORRIEN (19)3) e HAYMAN (1975), o qual por sua vez pode ser solubi lizado por ação microbiana, EIRA e CARVALHO (1970). Em meíos ácidos, os fosfatos de ferro e alumínio são solubilizados somente por ácidos que sequestram os cátions $\mathrm{Fe}^{+++}$e $\mathrm{Al}^{+++}$, o ácido que é ativo neste ponto de vista, é o ácido cítrico, seguido pelos ácidos succínico, málico, oxálico, tar tárico e lático, DOMMERGUES e MANGENOT (1970).

A adição de matëria orgânica influencia favoravelmente a solubilização de fósforo e diminui a sua fixação pór alumỉnio e ferro, BRADLEY e SIELING (1953). Admite-se que esta solubilização seja devido à ativação da flora microbiana, CASIDA (1959). EIRA e CARVALHO (1970) observaram que em solos inoculados e adicionados de matéria orgânica lpalha de cana e torta de algodão), o pH elevou-se em níveis significativos em relação ao solo estéril. A glicose por outro lado, levou a uma acidificação do so10. Concluiram ainda os autores que após e seleção inicial, os microrganis mos ao degradarem a matéria orgânica, influenciaram diretamente a acidez, de tal forma que esta passou a ser efeito e não causa. As produções de cafeei ro são aumentadas visivelmente pelo uso de "mulch" (aplicação de capim sêco ao solo). Este tratamento, além de outras vantagens, aumenta a concentração de fósforo nas folhas do cafeeiro, este aumento foi diretamente proporcional à quantidade de capim usado, LOTT et alii (1956). CARVALHO et alii (1977), num trabalho onde utilizaram solos tratados com diferentes fontes 
de carbono (resíduo de café, linhito e sacarose) e fosfato natural (apatita de araxä) constataram que na primeira semana de incubação obteve-s o máximo ni̊vel se solubilização, o qual baixou nas semanas seguintes, os autores sugeriram que este fenômeno ocorreu à imobilização microbiana, ou adsorção como fosfato trocável. No que diz respeito à utilização do fósforo pelas plantas, obtiveram resultados estatisticamente significativos, tanto no pêso como no nivel total do fósforo nas plantas. Por ordem decrescente, os melhores tratamentos foram: solo + apatita + resíduo de oafé, solo + apatita, solo * apatita + linhito, solo + residuo de café, solo * apatita + saca rose, solo + sacarose e solo + linhito, sendo que a sacarose apresentou pro blemas de fitotoxidez.

Segundo NAPLEKOVA (1966), citado por DOMMERGUES e MANGENOT (1970), os microrganismos celulolíticos estavam em assocjação com as bactérias solubilizadoras de fosfato, e assim se beneficiariam em solos pobres em fósforo assimilável, sem adubo fosfatato. Em solos podzílicos, a competição por fósforo é um fator importante, mas não suficiente para explicar a limitação à celulolise, isto pode ser atribuido à presença de produtos tóxi cos de plantas ou de origem microbiana, KONG e DOMMERGUES (1973b). A presença de certos elementos, mesmo em quantidades mínimas como traços l25 umo les/g solo) levam a uma inibição da atividade da fosfatase no solo. Os ele mentos que mostraram maior inibição à fosfatase ácida foram: $A g$, As, $W$, e Mo. Os maiores inibidores das fosfatases alcalinas foram: $\mathrm{Ag}$, Cd, $N$, As, etc, JUMA \& TABATABAI (1977).

Em certas espécies microbianas que são capazes de assimilar diretamente os fosfatos insolúveis, eles acumulam no interior de suas célu- 
las grandes quantidades de fósforc, parte sob a forma mineral (polifosfatos) e parta em formas organnicas. O fösforo permanece assim zmobilizado transitoriamente nas células microbiencs, e ë posteriormente liberado por diversos mecanismos: excreçẽo do ortoposfato pelas cëlulas que acumularam ortofosfatos, HAYMAN (1975), ou pela autólise das células bacterianas. Este fósforo pode ser colocado à disposiçõo das plantas, pela degradação dos ions ortofosfato proveniente de polifosfatos, pelas enzimas fosfatas do 5010. em moléculas fosfóntcas certos complexos fosförlcos orgênicos que podem penetrar no vegetal sem uma prẻvia mineralizaçêo. Este mecanísmo de solubilização em duas etapes, foj evidenciado por TARDLEUX-ROCHE (1966) e confirmado por NAPLEKOVA (1967), ci.tados por DOMMERGUES E MANGENOT (1970). A solubilização de fosfatos naturais não apresenta exígências ecológicas precisas, esta é uma daś razões da exístência de um grande número de espëcies de microrganismos envolvidos ro processo. A microflora solubilizadora de fosfato é senível ao fator $\mathrm{pH}$, sendo citado como influência favorável pHs elevados $(7,8$ a 7,9) para estas microflores, DOMURGUF'S \& MANGENOT (1970), embora a literatura aponte o aboixamerto do pH, como um dos fatôres da solu bilização, inclusive pela adição de enxófre, que incrementará a ação dos Thiobacillus, ALEXANDEF (1961), DOMAREGUE \& RANGENOT (1970) e FREIRE (1975).

Em meio hidromórfico ce teores de ácido orgânico ẻ elevado, em todo o solo e não sonente no interior de micro-habitats; é devido à abundància destes ácidos de origern microbiana que GASSER e BLOMFIELD (1955), citados por DOMMERGES e MANGENOT (1970), atribui o aumento da solubilização de fósforo férrico, pela decomposição de vegetais em anaerobiose. TA- 
DIEUX-ROCHE (1966), citados por DOMMERGUES e MANGENOT (1970), evidenciou que o teor no solo de matéria orgâníca humificada não influencia a densidade de microrganismus solubilizadores de fusfato. A contrário. a adição de matärla orgânica fresca age favoravelmente na proliferaça destes microrga nismos e induzem a ativação da solubilização. A mlor fora solublilizadora de fosfato é sensivelmente estimulada pela rizosfera, TARDIEUX -ROCHE (1966), citados por DOMMERGUES e MANGENOT (1970). HAYMAN (135) e SPERBER (1958); mas este estimulo nem sempre apresent uma caractariatica preferencialmente marcante, DOMMERGUES E MANGENOT (1970).

O fösforo é um fator limitante no desenvolvimento da microflo ra. A adição de fósforo em ambiente escasso no elemento, estimula as ativi dades microbianas, ao contrário do que se passa quando há reserva natural do elemento. A decomposição da matéria orgânica adicionada ao solo exige fósforo, se o material é pobre em fósforo (C/P alta), há exaurimento dos fosfatos disponíveis no solo, e redução da produção, a menos que seja feita fertilização, PURCHASE (1974), HAYMAN (1975) e HODSON (1973). PURCHASE (1974) observou que a deficiência de $P$ restringla a nitrificação e provocava respostas desprezíveis dos oxidantes de nitrato à aplicação de sais de amônia, pela inibição de seu crescimento. 


\section{MATERIAL E METODOS}

\subsection{Roteiro}

No presente trabalino foram avaliados os diversos grupamentos funcionais do ciclo do carbono e do nitrogênio em solos de cerrado, onde fo ram adicionados resíduos vegetais de espécies nativas e exöticas. Juntamen te com a avaliação do número mais provável de microrganismos dos vários gru pos funcionais, foram realizadas análises de fertilidade do solo, por análi sesquímicas e através do método de micro-Neubauer. Paralelamente foi monta do um experimento onde além dos resíduos vegetais, adicionou-se também fosfato de rocha e após incubação foi avaliado o fósforo solúvel em água e em äcido,

\subsection{Solo}

o solo utilizado no presente experimento foi proveniente de uma ărea pertencente à Fundação de Amparo à Pesquisa do Estado de São Pau10, localizada no Município de Itirapina, S.P., a uma altitude de $830 \mathrm{~m}$, com 
uma ärea total de 16 alqueires, apresentando vegetação típica de cerrado.

- local foi escolhido por nunca ter sido usado para estabelecimento anterior de lavouras. A área é protegjda contra devastaçöes atra vés de cerca de arame, e aceiro em toda a sua extensão. Esta proteção exis te a aproximadamente 25 anos. E as ünicas alterações que possam ter ocorrido, antes de serem tomadas as medidas de proteção, seriam eventuais queimadas.

A anälise do solo na ocasião da coleta é mostrada no Quadro 1.

QUADRO 1. Análise de fertilidade do solo usado no presente estudo, logo após sua coleta.

\begin{tabular}{|c|c|c|c|c|c|}
\hline $\begin{array}{c}\text { Acidez } \\
\text { pH }\end{array}$ & $\begin{array}{c}M . D . \\
\% C\end{array}$ & $\begin{array}{l}\text { Fósforo } \\
\text { e.m.g.PO } \mathrm{PO}_{4}\end{array}$ & $\begin{array}{l}\text { Potássio } \\
\text { e.m.g. } \mathrm{k \%}\end{array}$ & $\begin{array}{l}\mathrm{Ca}+\mathrm{Mg} \\
\mathrm{e} \cdot \mathrm{m} \cdot \mathrm{g} \cdot\end{array}$ & $\begin{array}{c}A l \\
e \cdot m \cdot g \cdot\end{array}$ \\
\hline 5,05 & 0.93 & 0,02 & 0,12 & 0.64 & 1.36 \\
\hline
\end{tabular}

3.3. Matéria Orgānica

A matéria orgânica adicionada foi de origem vegetal, sendo usadas 3 espécies nativas de cerrado selecionadas entre as mais frequentes na área e 2 espécies exóticas em reflorestamento. 
Quadro 2. Espécies vegetais usadas.

Nome científico

Rhynchospora exaltata

Ceasalphina spp.

Caesalpina bracteosa, TULL

Eucalyptus robusta. S.M.

Pinus alliotti Elgen var. elliotei nativa de cerrado

nativa de cerrado

nativa de cerrado

exótica

exỏtica

- Quadro 2 mostra as espécies vegetais usadas, e a anälise

química dos resíduos destes vegetais se encontra no Quadro 3 da pägina seguinte. 
42.

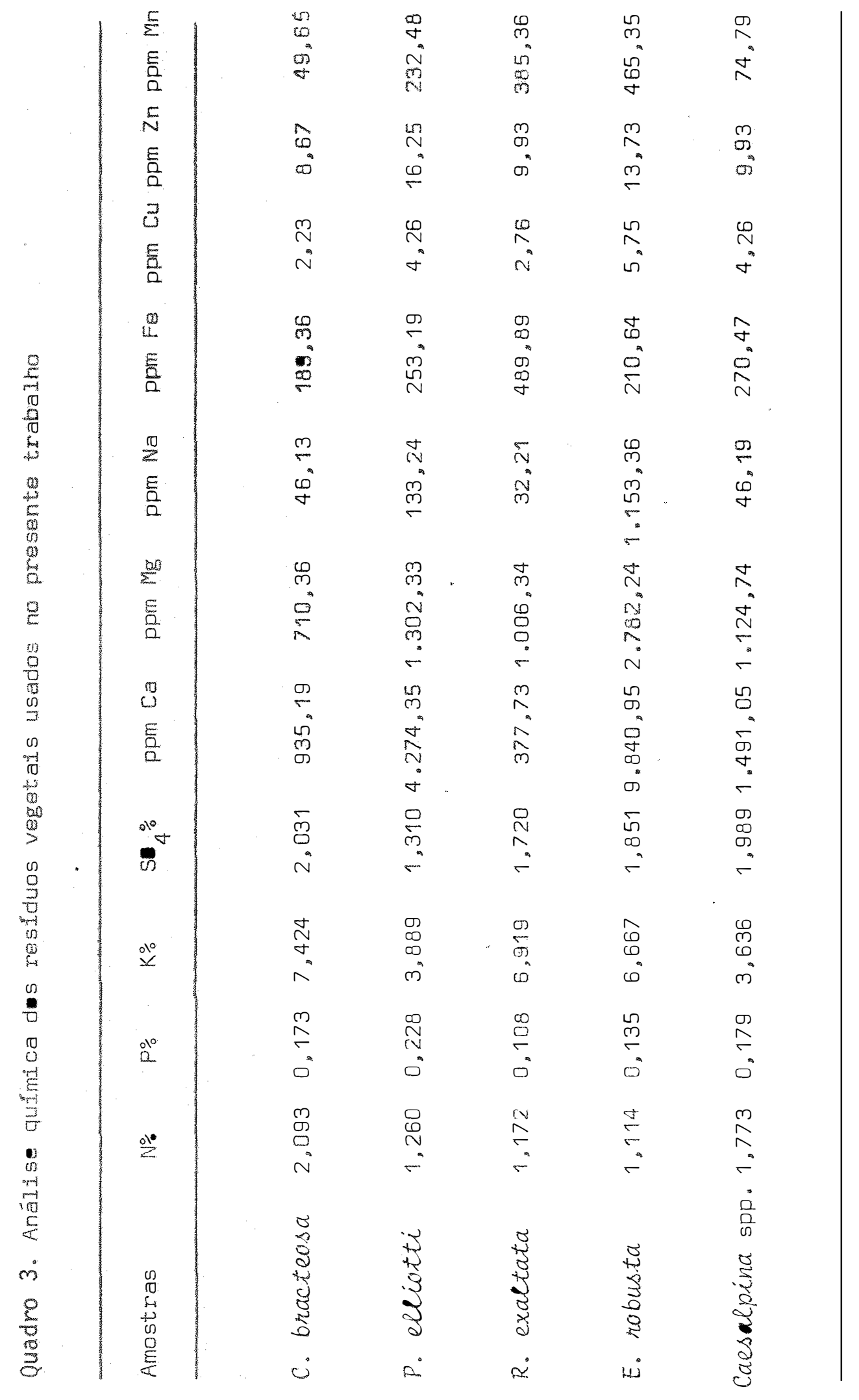




\subsection{Mejos de cultura}

Para as análises dos grupos funcionais foram usados os seguin tes meios de cultura:

Fixação aeróbia, Meio de TCHAN, citado por AUGIER, J. (1956): manitol (10g), carbonato de cálcio $(0,5 \mathrm{~g})$, solução salina (50 cc), extrato de terra (10 cc), solução de oligoelementos (1 cc), água destilada (c.e.), fixação anaeróbia. AUGIER, J. (1957): fosfato monopotássico $(0.75$ g), glicose (10 g), soda $1 / 10 \mathrm{~N}(33 \mathrm{ml})$, soluçäo salina $(50 \mathrm{ml})$, extrato de terra $(10 \mathrm{ml})$. solução de oligoelementos (1 ml), ägua destilada $0.8 .(1.000 \mathrm{ml})$, proteỏlise. IA AUDIE e CHALVIGNAC (1956): solução salina (50 ml), gelatzna $(30 \mathrm{~g})$, solução de oligoelémentos (1 $\mathrm{ml}$ ), água q.s.p. $(1.000 \mathrm{ml})$ ) amonifica ção, POCHON a TARDIEUX (1962): asparagina $(0.2 \mathrm{~g})$, solução salina (50 ml), solução de oligoelementos $(1 \mathrm{ml})$, ägua destilada $(950 \mathrm{ml})$ : nitrificação, COPPIE e BARAC (1952): meio para nitrosação - sulfato de amônia $(0,5$ g), carbonato de cálcio (1 g), solução salina (50 ml), água destilada (950 ml), meio para nitrificação - nitrito de sódio $(1 \mathrm{~g})$, carbonado de cálcio (1 g), solução salina (50 cc), água destilada (950cc): denitrificação, BARJAC (1952): nitrato de potássio (2 g), carbonato de cálcio (5 g), glicose (10 g), solução salina $(50 \mathrm{ml})$, solução de oligoelementos $(1 \mathrm{ml})$, água des tilada (950 ml),Amilolise, GIRARD, R. (1964): nitrato de amônia (1 g), amido $(1,5 \mathrm{~g})$, extrato de terra $(10 \mathrm{ml})$, solução salina $(50 \mathrm{ml})$, solução de oligoelementos ( $1 \mathrm{ml})$, água destilada q.S.P. $(1.000 \mathrm{ml})$; hemicelulolise, POCHON e TARDIEUX (1968); solução salina (50 ml), extrato de terra (3 ml), solução de oligoelementos ( $1 \mathrm{ml})$, nitrato de potássio $(0,3 \mathrm{~g})$, hemicelulose (1 g), carbonato de cálcio (1 g), água destilada q.s.p. (1.000 ml):celuloli 
.44.

se aeröbia, POCHON e TRADIEUX (1962): nitrato de amônia (1 g), extrato de terra (20 ml), solução salina $(50 \mathrm{ml})$, solução de oligoelementos (1 cc), água destilada q.S.P. (1.000 co): celulolise anaeróbia, POCHON \& TARDIEUX (1962): nitrato de amônia (2 g), carbono de câlclo ( $3 \mathrm{~g}$ ), extrato de terra. $(20 \mathrm{ml})$, solução salina $(30 \mathrm{ml})$, peptona $(1 \mathrm{~g})$, ägua destilada $q . \mathrm{s} . \mathrm{p} \cdot(1.000$ mi).

\subsection{Coleta do solo, da matéria orgânica e incubação dos värios tratamen tos}

o solo foi coletado a uma profundidade de $0-10 \mathrm{~cm}$, utilizando-se uma colher de jardinagem, a qual era desinfetada após cada amostra. As amostras foram tomadas em vários pontos da ärea (cerca de 60 amostras), formando assim uma única amostra composta. O solo foi levado para o laboratórie,onde foi feita a secagem ì sombra e à temperatura ambiente.

Foram coletados ramos e folhas no campo e colocados em estufa. a uma temperatura variando entre 50 a $80^{\circ} \mathrm{C}$, durante 3 dias. Em seguida as amostras foram trituradas em moinho e a sua granulometria padronizada em peneiras de furos com aproximadamente $0,2 \mathrm{~mm}$ de diâmetro. A matéria orgânỉca foi adicionada em uma proporção de $2 \%$ do pêso do solo, o qual foi incu bado em copos plásticos de $90 \mathrm{~g}$, distribuidos em blocos casualizados. Tal proporção foi conseguỉda através do pêso sêco de matérỉa orgânica e do solo.

Para cada tipo de vegetal foram feitos dois tratamentos no processo de incubação: condições aeróbias $\{60 \%$ da c.c.) e anaeróbias (110\% da c.c.J sendo que cada um com 15 repetições. Os mesmos tratamentos foram 
feitos com solos sem adição de M.o., que serviu como testemunha.

Os vasos foram pesados após a adiçấo do material e de ägua, cobertos com polietileno, e a água perdida por evaporação reposta periodicamente, pela diferença de pêso.

Durante o período de incubação a temperatura oscilou entre $27^{\circ}$ a $34^{\circ} \mathrm{C}$

Foram realizadas leituras para verificação da atividade dos grupamentos microbianos funcionais que foram avaliadas segundo as técnicas de POCHON e TARDIEUX, e os resultados transformados em nümero mais provável de microrganismos por grama de solo, utilizando-se a tabela de Maccrady.

Foram avaliados os seguintes grupos: hemicelulolíticos, celu lolíticos (aeróbios e anaeróbios). Amilolíticos, Proteolíticos, Nitrificantes (nitritação e nitratação), Denitrificação. Fixação (aeróbia e anaeróbia) de Nitrogênio e Flora total.

Para a inoculação foram retirados ao acaso 5 vasos de cada tratamento, que foram em seguida colocados em moinho de bola, marca NORTON, homogeneizadas e pesadas. De cada amostra de solo foram pesadas $20 \mathrm{~g}$ e dissolvidas em frascos contendo $180 \mathrm{ml}$ de H2O destilada esterilizada, deixadas em agitador durante 10' para homogeneizar. Em seguida procedia-se a diluição em série.

As amostras para anälise foram colhidas antes da incubação, e após três e seis meses de incubação. 


\subsection{Bio Ensaio}

Paralelamente as determinações microbiológicas nos mesmos pe ríodos foram feitos ensaios visando-se avaliar a fertilidade dos solos. Es tes ensaios foram feitos utilizandorse a técnica de Neubauer modificada por CATANI e BERGAMIN (1961), com 5 repetĩcöes para cada tratamento.

A avaliação foi feita através de pêso seco do material. 0 ar roz utilizado no experimento foi e variedade IAC 435.

Anälise de Fertilidade do solo

Foram realizadas análises do solo, levando-se em conta o pH, carbono orgânico \%, Fósforo, Potássio, Cálcio, Magnésio, Alumínio e Hidrogênio. Estas análises foram realizadas nos mesmos períodos das análises mi crobibiológicas. (antes da incubação e após 3 e 6 meses\}.

\subsection{Incubação com Adỉção de Fosfato Natura]}

Solo com uma adição de $2 \%$ de M.O. de peso do solo, onde também foi adicionado $0,2 \%$ de fosfato (fosfato de Olinda). E incubados em vasos com aproximadamente $90 \mathrm{~g}$ de cada um e cobertos com plásticos (polietileno), e em condições aeróbias e anaeróbias com 10 repetições, 5 para cada leitura.

Os períodos de incubação foram de 7 a 15 dias após o qual foram feitas análises químicas de fósforo solúvel em ácido $\left(\mathrm{H}_{2} \mathrm{SO}_{4} 0.5 \mathrm{~N}\right)$ e em água, e os resultados comparados com o solo sem adição de M.O.. mas adi cionado fosfato e inbucado nas mesmas condições que os solos com M.O.. 


\section{RESULTADOS}

4.1. Avaliação do nümero mais provāvel de microrganismos

Quadro 1. Influência de resíduo vegetal e de incubação do solo após 3 e meses em condições de aerobiose e anaerobiose sobre $0 n^{8}$ de $m^{4}-$ crorganismos hemicelulolíticos por grama de solo. População inicial: $2,5 \times 10^{12}$ microrg. /grama de solo.

Tratamento Incubação em Aerobiose

3 meses

c. bracteosa

$250 \times 10^{12}$

P. ellottii $250 \times 10^{12}$

$R$. exaltata $95 \times 10^{12}$

E. robusta $250 \times 10^{12}$

Caesalpina spp. $30 \times 10^{12}$

Sem M.O.
6 meses

$250 \times 10^{12}$

$250 \times 10^{12}$

$250 \times 10^{12}$

$9,5 \times 10^{12}$

$250 \times 10^{12}$

$9,5 \times 10^{12}$
Incubação em Anaerobiose

3 meses

6 meses

$\begin{array}{ll}250 \times 10^{12} & 250 \times 10^{12} \\ 95 \times 10^{12} & 250 \times 10^{12} \\ 250 \times 10^{12} & 250 \times 10^{12} \\ 250 \times 10^{12} & 95.0 \times 10^{12} \\ 250 \times 10^{12} & 250 \times 10^{12} \\ 4.0 \times 10^{12} & 2.0 \times 10^{12}\end{array}$


Quadro 2. Influência de resíduo vegetal e da incubação do solo apōs 3 e 6 meses em condiçães de aerobiose e anaerobiose sôbre $0 n^{8}$ de microrganismos amilolíticos por grama de solo. População inicial: $2,5 \times 10^{10}$ microrg./grama de solo.

\begin{tabular}{lcccc}
\hline Tratamento & \multicolumn{1}{c}{ Incubação em Aerobiose } & Incubação em Anaerobiose \\
& $\begin{array}{l}3 \text { meses } \\
\text { C. bracteosa }\end{array}$ & 6 meses & 3 meses & 6 meses \\
P. elliottii & $0,01 \times 10^{10}$ & $45 \times 10^{10}$ & $2,5 \times 10^{10}$ & $95 \times 10^{10}$ \\
R. exaltata & $0,11 \times 10^{10}$ & $95 \times 10^{10}$ & $1,5 \times 10^{10}$ & $95 \times 10^{10}$ \\
E. robusta & $1,5 \times 10^{10}$ & $80 \times 10^{10}$ & $0,2 \times 10^{10}$ & $20 \times 10^{10}$ \\
Caesalpina spp. & $0,01 \times 10^{10}$ & $250 \times 10^{10}$ & $2,0 \times 10^{10}$ & $1,5 \times 10^{10}$ \\
Sem M.0. & $0,1 \times 10^{10}$ & $250 \times 10^{10}$ & $1,1 \times 10^{10}$ & $95 \times 10^{10}$ \\
\hline
\end{tabular}

Quadro 3. Influência de resíduo vegetal e da incubação do solo após 3 e 6 meses em condições de aerobiose e anaerobiose sôbre $0 n^{8}$ de $\mathrm{mi-}$ croorganismos celulolíticos aeröbios por grama de solo. População inicial: 95 microrg./grama solo.

\begin{tabular}{lcccc}
\hline & \multicolumn{1}{c}{$\begin{array}{l}\text { Incubação em Aerobiose } \\
\text { Tratamento }\end{array}$} & $\begin{array}{l}\text { Incubação em Anaerobiose } \\
\text { meses }\end{array}$ & $\begin{array}{l}\text { Ines } \\
3 \text { meses }\end{array}$ & 6 meses \\
\hline C. bracteosa & 40 & 200 & 30 & 150 \\
P. elliotti & 40 & 150 & 90 & 250 \\
R. exaltata & 30 & 150 & 90 & 250 \\
E. robusta & 40 & 200 & 0 & 30 \\
Caesalpina spp & 110 & 95 & 140 & 45 \\
Sem M.0. & 90 & 75 & 70 & \\
\hline
\end{tabular}


Quadro 4. Influência de resíduo vegetal e da incubação do solo após 3 e 6 meses em condições de aerobiose e anaerobiose sôbre $0 n^{8}$ de microrganismos celulolíticos anaerábios por grama de solo. População inicial: 150 microrg./grama de solo.

\begin{tabular}{|c|c|c|c|c|}
\hline \multirow{2}{*}{ Tratamento } & \multicolumn{2}{|c|}{ Incubação em Aerobiose } & \multicolumn{2}{|c|}{ Incubação em Anaerobiose } \\
\hline & 3 meses & 6 meses & 3 meses & 6 meses \\
\hline C. bracteosa & 7 & 9 & zero & 450 \\
\hline P. elliottii & zero & 11 & zero & 140 \\
\hline R. exaltata & zero & 200 & 11 & 35 \\
\hline E. robusta & zero & 4 & zero & 4 \\
\hline Caesalpina spp. & 3 & zero & zero & 4 \\
\hline Sem M.O. & 4 & zero & zero & 7 \\
\hline
\end{tabular}

Quadro 5. Influência de resíduo vegetal e da incubação do solo após 3 e 6 meses em condições de aerobiose e anaerobiose sōbre o $n^{*}$ de microrganismos da flora total por grama de solo. População inicial: $20 \times 10^{7}$ microrg./grama de solo.

Tratamento

Incubação em Aerobiose

3 meses

E meses
Incubação em Anaerobiose

3 meses

6 meses
$35.0 \times 10^{7}$
$0,5 \times 10^{7}$

$$
14 \times 10^{7}
$$$$
60 \times 10^{7}
$$
$3,0 \times 10^{7}$
$1,4 \times 10^{7}$
R. exaltata
E. robusta
Caesalpina spp.
Sem M.O.

$$
20 \times 10^{7}
$$
$9.5 \times 10^{7}$
C. bracteosa
$1,4 \times 10^{7}$
$35,0 \times 10^{7}$
$2.5 \times 10^{7}$
P. elliottii
$2.0 \times 10^{7}$
$14 \times 10^{7}$
$1,4 \times 10^{7}$
$17 \times 10^{7}$
$1,1 \times 10^{7}$
$11,0 \times 10^{7}$
$1.7 \times 10^{7}$
$0.4 \times 10^{7}$
$0.7 \times 10^{7}$
$1.1 \times 10^{7}$
$2 \times 10^{7}$ 
Quadro 6. Influência de resíduo vegetal e da incubação do solo apős 3 e 6 meses em condições de aerobiose e anaerobiose sôbre o $n^{\circ}$ de microrganismos proteolíticos por grama de solo. População inicial:0,95× $10^{8} \mathrm{microrg./grama} \mathrm{de} \mathrm{solo.}$

\begin{tabular}{|c|c|c|c|c|}
\hline \multirow{2}{*}{ Tratamento } & \multicolumn{2}{|c|}{ Incubação em aerobiose } & \multicolumn{2}{|c|}{ Incubação em anaerobiose } \\
\hline & 3 meses & $\varepsilon$ meses & 3 meses & 6 meses \\
\hline C. bracteosa & $250 \times 10^{8}$ & $250 \times 10^{8}$ & $250 \times 10^{8}$ & $250 \times 10^{8}$ \\
\hline P. elliottii & $250 \times 10^{8}$ & $250 \times 10^{8}$ & $95 \times 10^{8}$ & $250 \times 10^{8}$ \\
\hline R. exaltata & $250 \times 10^{8}$ & $250 \times 10^{8}$ & $11,0 \times 10^{8}$ & $250 \times 10^{8}$ \\
\hline E. rabusta & $15 \times 10^{8}$ & $250 \times 10^{8}$ & $1,15 \times 10^{8}$ & $250 \times 10^{8}$ \\
\hline Caesalpina spp. & $250 \times 10^{8}$ & $250 \times 10^{8}$ & $250 \times 10^{8}$ & $250 \times 10^{8}$ \\
\hline Sem M.O. & $20 \times 10^{8}$ & $20 \times 10^{8}$ & $0.15 \times 10^{8}$ & $25 \times 10^{8}$ \\
\hline
\end{tabular}

Quadro 7. Influência de resíduo vegetal e-da incubação do solo após 3 e 6 meses em condições de aerobiose e anaerobiose sōbre o $n^{8}$ de microrganismos amonificantes por grama de solo. População inicial: $0.25 \times 10^{10}$ microrg./grama de solo.

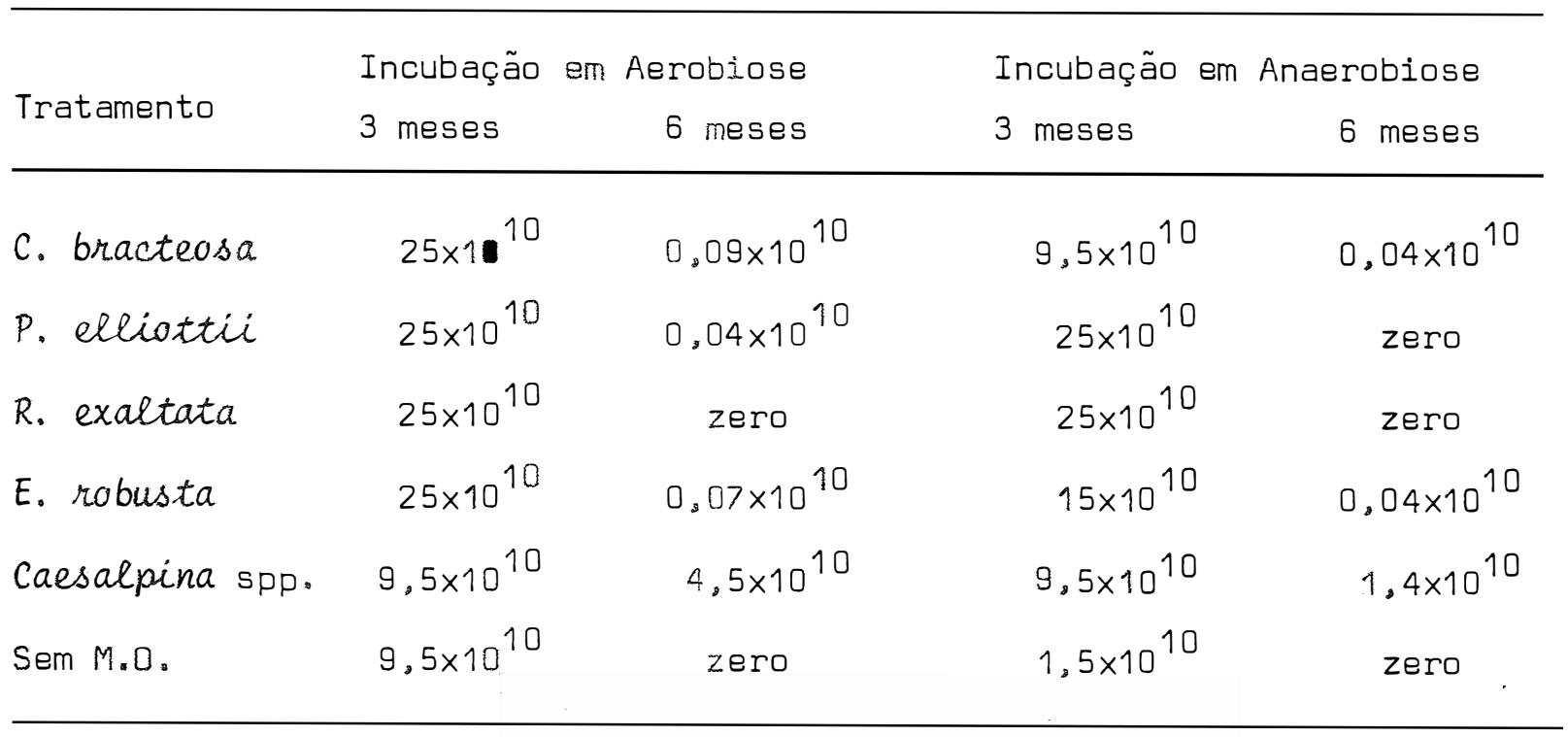


Quadro 8. Influência de resíduo vegetal e da incubação do solo após 3 e 6 meses em condições de aerobiose e anaerobiose sôbre o $n^{\circledR}$ de microrganismos nitrificantes (nitritação) por grama de solo. População inicial: $25 \times 10^{3} /$ grama de solo.

\begin{tabular}{lcccc}
\hline & Incubação em Aerobiose & \multicolumn{1}{c}{ Incubáção em Anaerobiose } \\
Tratamento & 3 meses & 6 meses & 3 meses & 6 meses \\
\hline C. bracteosa & zero & $0,4 \times 10^{3}$ & $5 \times 10^{3}$ & $0,5 \times 10^{3}$ \\
P. elliottii & zero & zero & zero & zero \\
R. exaltata & zero & $0,2 \times 10^{3}$ & zero & zero \\
E. robusta & $17,0 \times 10^{3}$ & $0,7 \times 10^{3}$ & $9,0 \times 10^{3}$ & $0,9 \times 10^{3}$ \\
Caesalpina spp. & zero & $0,5 \times 10^{3}$ & zero & $0,7 \times 10^{3}$ \\
Sem M.0. & & & &
\end{tabular}

Quadro 9. Influência de resíduo vegetal e da incubação do solo após 3 e 6 meses em condições de aerobiose e anaerobiose sôbre $0 n^{8}$ de $\mathrm{mi-}$ crorganismos nitrificantes (nitratação) por grama de solo. População inicial: 2 microrg./grama de solo.

\begin{tabular}{|c|c|c|c|c|}
\hline \multirow{2}{*}{ Tratamento } & \multicolumn{2}{|c|}{ Incubação em Aerobiose } & \multicolumn{2}{|c|}{ Incubação em Anaerobiose } \\
\hline & 3 meses & 6 meses & 3 meses & 6 meses \\
\hline c. bracteosa & 1400 & 700 & zero & zero \\
\hline P. elliottii & 60 & 200 & zero & zero \\
\hline R. exaltata & 500 & 200 & zero & zero \\
\hline E. robusta & zero & zero & zero & zero \\
\hline Caesalpina spp. & 4 & 200 & zero & zero \\
\hline Sem M.O. & 9 & zero & 2 & zero \\
\hline
\end{tabular}


Quadro 10. Influência de resíduo vegetal e da incubação do solo apös 3 e 6 meses em condições de aerobiose e anaerobiose sôbre o $n^{\circ}$ de microrganismos denitrificantes por grama de solo. Mopulação inicial: $2.0 \times 10^{5}$ microrg./grama de solo.

\begin{tabular}{|c|c|c|c|c|}
\hline \multirow[b]{2}{*}{ Tratamento } & \multicolumn{2}{|c|}{ Incubação em aerobiose } & \multicolumn{2}{|c|}{ Incubação em Anaerobiose } \\
\hline & 3 meses & 6 meses & 3 meses & 6 meses \\
\hline c. bracteosa. & $250 \times 10^{5}$ & $0,04 \times 10^{5}$ & $25,0 \times 10^{5}$ & $0,25 \times 10^{5}$ \\
\hline P. elliottii & $25 \times 10^{5}$ & $0.11 \times 10^{5}$ & $3,0 \times 10^{5}$ & $0.07 \times 10^{5}$ \\
\hline R. exaltata & $3,0 \times 10^{5}$ & $0,15 \times 10^{5}$ & $25 \times 10^{5}$ & $0,09 \times 10^{5}$ \\
\hline E. robusta & $7,5 \times 10^{5}$ & $20,0 \times 10^{5}$ & $3,0 \times 10^{5}$ & $1,5 \times 10^{5}$ \\
\hline Caesalpina spp. & $250 \times 10^{5}$ & $0.2 \times 10^{5}$ & $25,0 \times 10^{5}$ & $0,2 \times 10^{5}$ \\
\hline Sem M.O. & $30 \times 10^{5}$ & $0.3 \times 10^{5}$ & $250 \times 10^{5}$ & $0.15 \times 10^{5}$ \\
\hline
\end{tabular}

Quadro 11. Influência de resíduo vegetal e da incubação do solo após 3 e 6 meses em condições de aerobiose e anaerobiose sôbre o $n^{\circledR}$ de microrganismos fixadores aeróbios de nitrogênio por grama de solo. População inicial: zero mirctorg./grama de solo.

\begin{tabular}{|c|c|c|c|c|}
\hline Tratamento & $\begin{array}{l}\text { Incubação } \\
3 \text { meses }\end{array}$ & $\begin{array}{r}\text { em Aerobiose } \\
6 \text { meses }\end{array}$ & $\begin{array}{l}\text { Incubaçã } \\
3 \text { meses }\end{array}$ & $\begin{array}{l}6 \text { robiose } \\
6 \text { meses }\end{array}$ \\
\hline c. bracteosa & zero & 4 & 25 & 8 \\
\hline P. alleottii & 95 & 12 & 35 & 9 \\
\hline R. exaltata & 250 & 7 & 25 & 2 \\
\hline E. robusta & 35 & 14 & 7 & 8 \\
\hline Caesalpina spp & 5 & 11 & 25 & 7 \\
\hline Sem M.O. & 20 & 7 & 13 & 5 \\
\hline
\end{tabular}


Quadro 12. Influência de resíduo vegetal e da incubação do solo após 3 e 6 meses em condições de aerobiose e anaerobiose sôbre $0 n^{\circledR}$ de microrganismos fixadores anaeróbios de nitrogênio por grama de so10. População inicial: $0,025 \times 10^{3}$ microrg./grama de solo.

\begin{tabular}{|c|c|c|c|c|}
\hline Tratamento & \multicolumn{2}{|c|}{ Incubação em aerobiose } & \multicolumn{2}{|c|}{ Incubação em Anaerobiose } \\
\hline C. bracteosa & zero & $3,5 \times 10^{3}$ & $5,0 \times 10^{3}$ & $0,025 \times 10^{3}$ \\
\hline P. elliottii & $17,0 \times 10^{3}$ & $1.7 \times 10^{3}$ & $25 \times 10^{3}$ & $8,0 \times 10^{3}$ \\
\hline R. exaltata & $0,35 \times 10^{3}$ & $0,8 \times 10^{3}$ & $0,14 \times 10^{3}$ & $25 \times 10^{3}$ \\
\hline E. robusta & $0,02 \times 10^{3}$ & $1.1 \times 10^{3}$ & $0,02 \times 10^{3}$ & $13 \times 10^{3}$ \\
\hline Caesalpina spp. & zero & $0,35 \times 10^{3}$ & zero & $3,0 \times 10^{3}$ \\
\hline Sem M.O. & $0,02 \times 10^{3}$ & $0,04 \times 10^{3}$ & $0,02 \times 10^{3}$ & $1,6 \times 10^{3}$ \\
\hline
\end{tabular}

\subsection{Micro-Neubauer}

Quadro 13. Método de Neubauer modificado por CATANI e BERGAMIN (1961). Resultado expresso em gramas de péso sêco de plantas de arroz cultivadas em solos incubados com e sem adição de resíduo de várias espëcies vegetais, durante 3 e 6 meses, em condições de aerobiose e anaerobiose.

\begin{tabular}{lcccc}
\hline Tratamento & $\begin{array}{c}\text { Solo } \\
3 \text { meses }\end{array}$ & $\begin{array}{c}\text { Incubado em Aerobiose } \\
6 \text { meses }\end{array}$ & $\begin{array}{c}\text { Solo } \\
3 \text { meses }\end{array}$ & 6 meses \\
\hline C. bracteosa & 3,69 & 6,92 & 4,53 & 8,73 \\
P. elliottii & 4,20 & 7,95 & 4,23 & 6,19 \\
R. exaltata & 5,55 & 6,36 & 4,07 & 5,10 \\
E. robusta & 5,17 & 5,73 & 3,70 & 6,19 \\
Caesalpina spp. & 3,75 & 3,79 & 3,30 & 4,43 \\
Sem M.0. & 3,39 & 4,13 & 3,47 & 4,26 \\
\hline
\end{tabular}




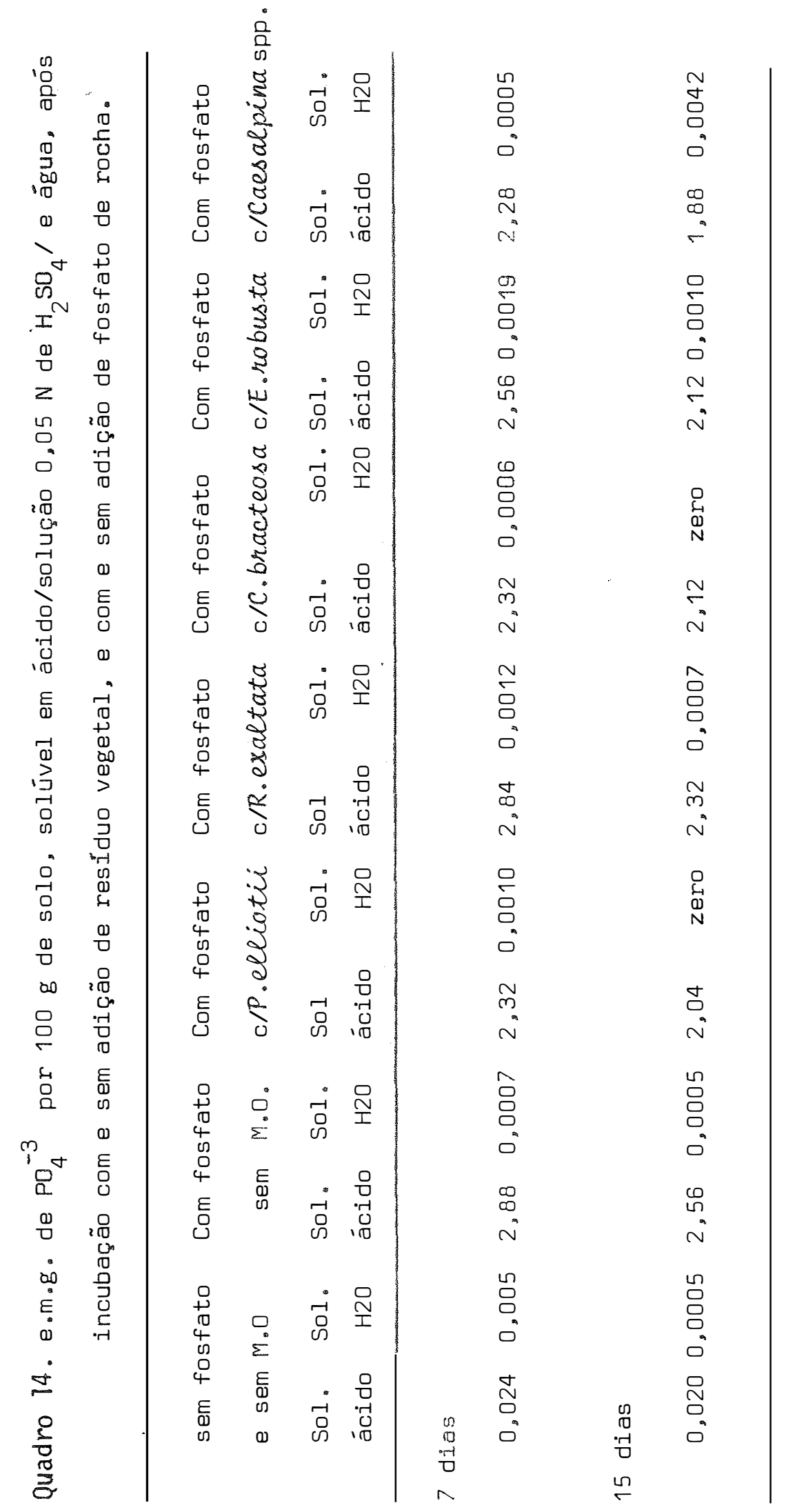




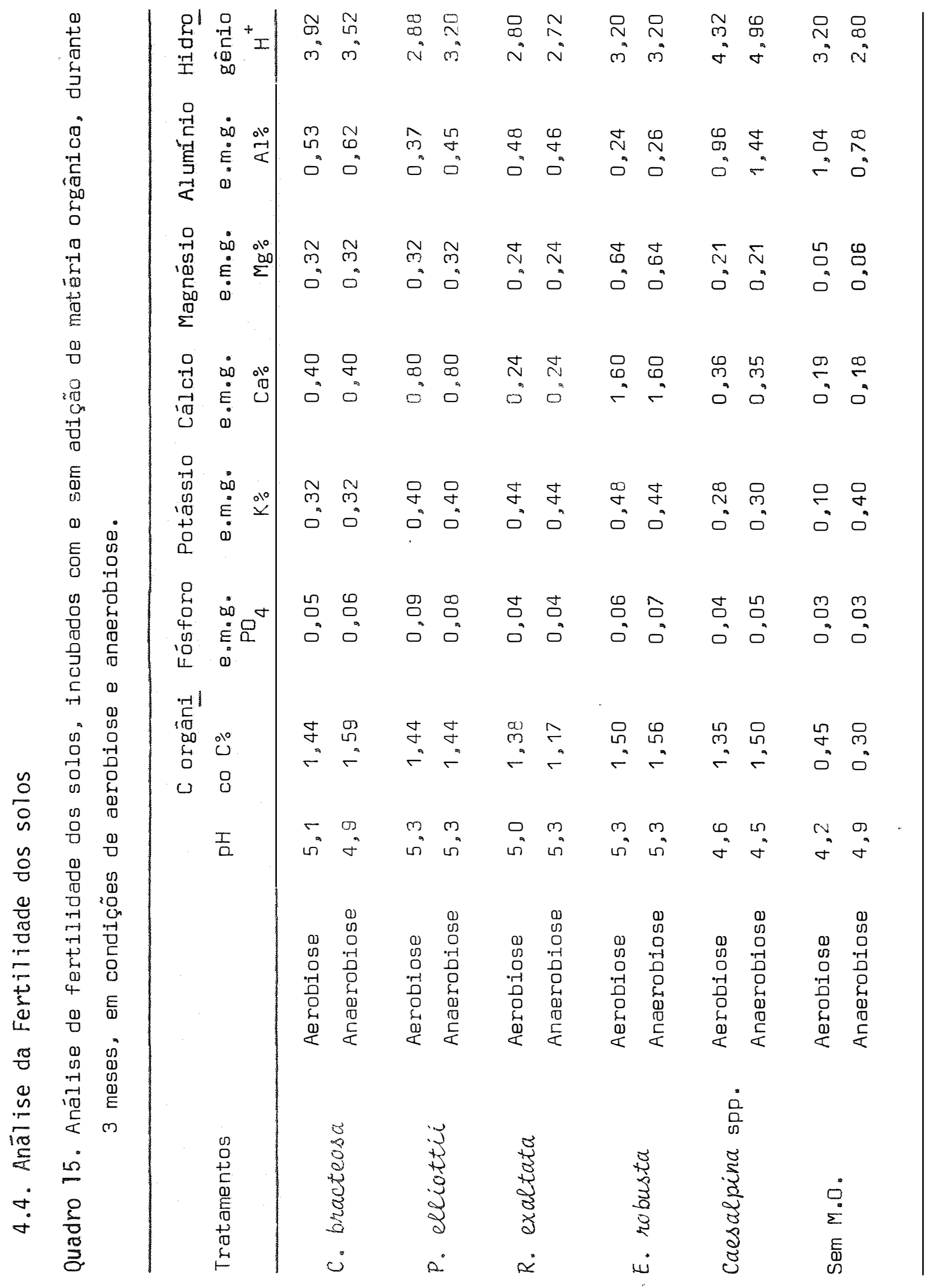




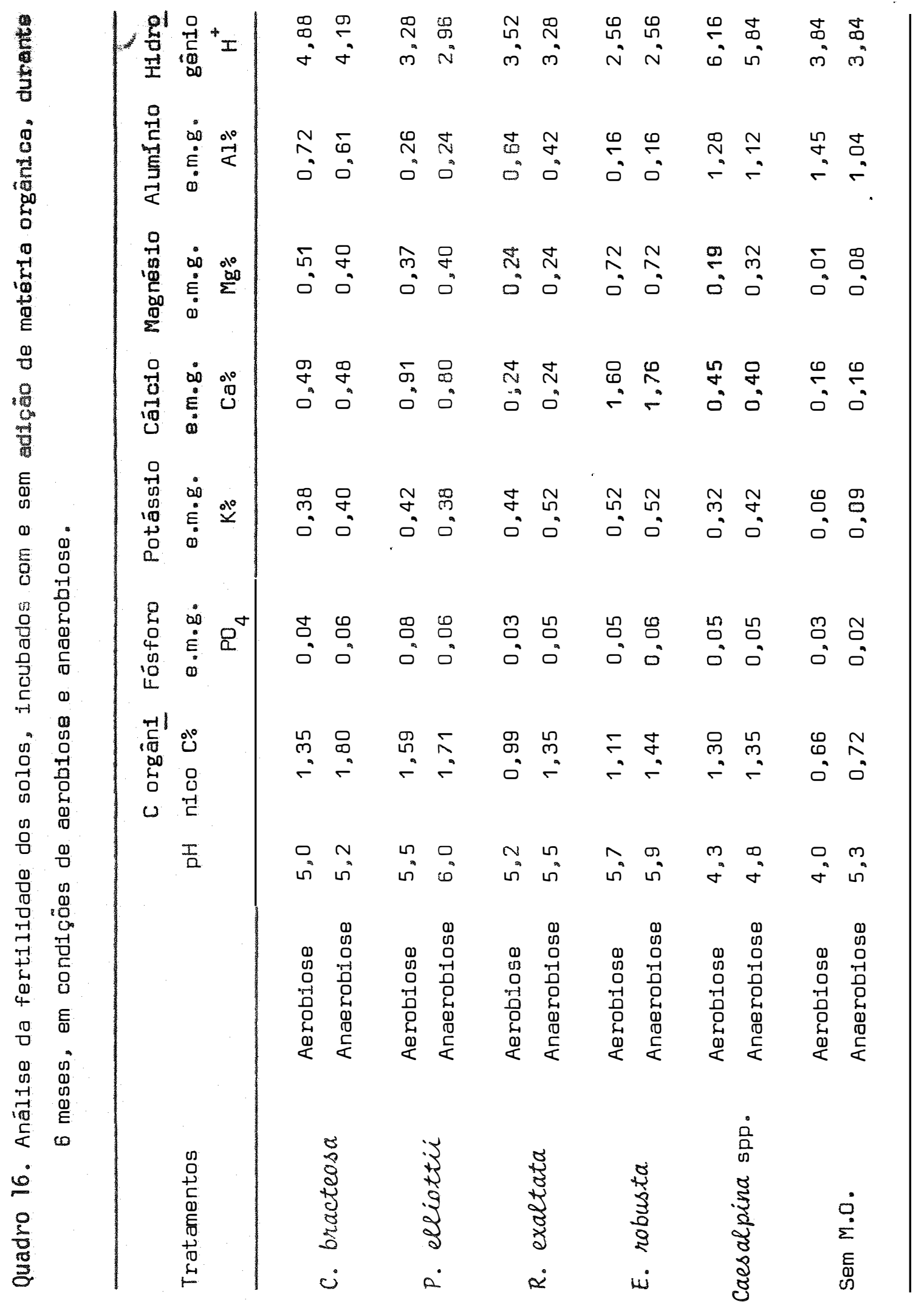




\section{DISCUSSÃO}

\subsection{Nümero mais provävel de microrganismos (ciclo do carbono e nitrogê- nio)}

Para realização do presente trabalho foram escolhidas cinco espécies vegetais, três espëcies nativas do cerrado e que eram representati vas no local da coleta, e duas exóticas a este ecossistema, mas que tem sido introduzidas nestes solos com frequêncỉa, em projetos de reflorestamento.

o solo utilizado e onde foi incorporado a matéria orgânica, foi incubado em "condições de 60\% de capacidade de campo, que chamaremos de aerobiose, onde existe uma boa difusão de gases, e nestas condições, grande parcela da população microbiana é beneficiadas menos as extritamente anaeró bias, SEIFERI (1960), (1961) e GONDO (1961) citados por MACLAREN e SKUJINS (1968). E em condições de 110\% da capacidade de campo, que chamaremos de anaerobiose, visto que a carência de oxigênio é acentuada nestas condições, e suprime os aeróbios obrigatórios, bem como a maioria da microflora e fungos, RUSSELL (1968), SWABY (s/d), CURRIE (1962). Estes termos servem também 
para facilitar a citação dos tratamentos.

Na incubação de solos foram mantidas constantes as condições de umidade, e as de temperatura com pouca variagäo(27 a $34 \mathrm{C}$ ). No solo estas condições variam com a estação do ano e com as varjậ̃ôs diumas, fato que deve ser levado em consideração nas comparações feìtas com dados obtidos por outros autores.

Avaliando-se as populações nos grupamentos funcionais, notou-se que a população inicial de mỉcrorganismos amilolíticos é alta, compa rando-se com referências citadas por ALEXANDER (1961), TOSIN et alii (1976) e TOSIN (1977). De modo geral houve um pequeno aumento após seis meses de incubação, quando comparado com três meses. Fato que pode ser aceito, levando-se em consideração que a degradação do amido não envolve uma mícroflo ra específica, CHALVIGNAC (1953), e adicionando-se resíduo vegetal teríamos sem dúvida um aumento da população microbiana do solo, ALEXANDER(1.961), DOMMERGUES e MANGENOT (1970). Ainda segundo observações feitas por BARJAC e CHALVIGNAC (1954), o amido é degradado rapidamente em solos férteis, menos rápido em solos não férteis, e vagarosamente em solos turfosos.

Todos os resíduos adicionados aumentaram a população de hemi celulolíticos, em comparação com o solo sem adição de matéria orgänỉca. Em E. robusta, notou-se uma diminuição acentuada na população após seỉs meses de incubação, evidenciando uma räpida mineralização, TOSIN (1977). Fato que deveria levar a um incremento dos degradadores da celulose, o que não ocorreu no presente estudo, onde observou-se uma população original baixa, comparando-se com dados encontrados por ALEXANDER (1961) e TOSIN et alii 
(1976). E mesmo após adição de resíduos vegetais nos värỉos tretamentos, não houve aumento significativo. A população de celulolíticos na incubeçóo em anaerobiose, foi menor ainda evidenciando uma aixa populaço de clostri dium spp.

o baixo nümero de celulolíticos encontrados pode estar associado ao baixo teor do nitrogênio, que é um dos fatores crîticos na degrada ção da celulose. IMSHENETSKY (1968), GRAY e WILLIAMS (1971), CLARK (1968), KONG E DOMMERGUES (1973a), BIRCH (1958), KUBISTA (1972) \& SANTOS (1977). E xistem também evidências de que a produção de celulose é marcadamente inibi da pala microflora do nitrogênio, KONG e DOMMERGUES (1973b), e foram observaram baixas populações de nitrificadores, e os amonificantes e proteolíticos apacerem em número elevado, embora estes dois ültimos grupamentos funcionais não sejam específicos, e com o enriquecimento do solo, deve ter havido também um aumento da populaçäo total. A deficiêncỉa em fósforo pode também ser um fator limitante à celulolise, KONG e DOMMERGUES (1973a), e comprovadamente. (ver anälise de fertilidade Quadros 15 e 16 ) o fósforo nes tes solos é muito baixo. Um aumento na degradação da celulose foi consegui do, pela adição de $N$ e P usados em conjunto por TODOROVA e BENEVSKY (1971).

O nümero de mícrorganismos proteolíticos aumentou sỉngificativamente em relação ao solo original, e a solo incubado sem adição de matérỉa orgânica, após seis meses de incubação, fato que é marcante no solo incubado anaerobicamente (Quadro b). Ocorrência inversa foi observada nos amonificantes, onde a maior população foỉ encontrada após 3 meses. o que contradiz observações feitas por KENDRICK e BURGES (1962), citados porTOSIN 
(1977), \& também o último autor que afirma que as acículas de Pinus ficam aproximadamente intactas por seis meses, quando se inicia, sua decomposição. Contradição onde se deve levar em conta que no presente trabalho, a matéria orgânica de Pinus, assim como as demais, foram trituradas após seca gem, antes de serem incorporadas ao solo, e colocadas em temperatura de incu bação variando entre 27 a $34^{\circ} \mathrm{C}$, que diferem das condições temperadas citadas.

O aumento verificado no $\mathrm{pH}$ do solo (Quadro 15 e 16), pode es tar associado à alta amonificação inicial, SMILEY e PAPENDICK (1967) e KIEHL e ROCHA FILHO (1972), e este aumento manteve-se devido à baixa atividade ni trificadora, observada em todos os tratamentos. Aliado ao fato que, sendo - solo em estudo de textura arenosa, a variação do pH é mais afetada devido ao seu baixo poder tamponante, KIEHL e COBRA NETTO (1976).

A adição de matéría orgânica não incrementou o desenvolvimen to de uma microflora nitrificante, que era inicialmente baixa. Sendo os so los de cerrado extremamente pobres, este fato coincide com a afirmação de CHASE et alii (1968), de que a nitrificação biológica é usada como indicadora da fertilidade, ALLISON e STERLING (1949), citados por ALEXANDER (1961), demonstraram um correlação entre o conteúdo de $N$ total e a liberação de nitrito da fração orgânica do solo, sendo a magnitude do processo de pende do conteúdo de $N$ do liter. A baixa capacidade de nitrificação de alguns solos resulta primariamente da baixa população de organismos nitrificantes, HEILMAN (1974). O pH exerce uma grande influência na nitrificação, em ambientes ácidos, a marcha é lenta, como atestam experimentos realizados 
em solos ácidos de florestas, mesmo com o aumento de $\mathrm{NH}_{4}$. THEOBALDI e SMITH (1974), CALLE e VELLASCO (1972) e SANTOS (1977), o que poderia explicar a baixa população nitrificadora encontrada no solo em estudo. Em culturas de enriquecimento a nitrificação dificilmente ocorre em pH abaixo de 6,0, WEBER e GAINER (1962). o pouco nitrito produzido pode desaparecer através de assimilação por microrganismos, CUTLER e MUKERJI (1931), citados por ALEXANDER (1961). E conhecido ainda que diversas plantas, incluindo gramíneas e flores de verão produzem substâncias antimicrobianas, como ácido clorogênico e taninos, que suprimem a nitrificação BOUGHY et alii (1964), RTCE(1965) e STIVEN (1952).

Se o liter de uma vegetação inibe a microflora nitrificadora, e não a amonificação, a inibição da nitrificação, pode ter as mesmas consequências favoráveis que a aplicação de inibidores de síntese de nitratos, o que beneficiaria a vegetação, principalmente as coníferas que utilizam o $N$ amoniacal, ao passo que plantas decíduas preferem nitratos, CHASE et alii (1968).

Certos tipos de liter são inibidores de microrganismos, agin do principalmente sobre as bactérias nitrificantes e fixadoras de nitrogênio, pertencentes aos gêneros Azotobacter e Beijerinckia, sendo particularmente marcante nas confferas, BAUZON et alii (1969), citado por TOSIN (1977)。

Regra geral a denitrificação foi maior após três meses, decrescendo aos seis meses, sendo sensivelmente mais baixa em tratamentos onde foram adicionados resíduos vegatais de $P$. elliottii, $R$. exaltata $e E$. 
robusta. 0 que confirma observações de DOMMERGUES e MANGENOT (1970). de que a denitrificação é afetada pela natureza da matéria orgânica adicionada, e que a denitrificação biológica é favorecida pela adição de resíduos. A denitrificação em anaerobiose não apresentou diferenças significativas em relação aos solos incubados em aerobiose, o que concide com informações recentes, BOLLAG et alii (1970), DELWICHE e BRYAN (1976) e SKINER (1968). Não existe uma especificidade dos organismos responsáveis pela denitrificação, então em meio de cultura para avaliação de denitrificantes, na verdade, podem estar presentes uma grande variedades de microrganimsos. A temperatura de incubação, que permaneceu próxima dós $30^{\circ} \mathrm{C}$, é favorável à denitrifica ção, segundo observações feitas por DELWICHE e BRYAN (1976).

A conversão de ions nitritos em produtos gasosos, em condições estéreis, é geralmente favorecida pelo ion hidrogênio. Na é produzido em baixos níveis em $\mathrm{pH}_{3}$ entre 6,0 e 7,0, mas sob condições mais ácidas, NO é produzido em altos níveis, DELWICHE e BRYAN (1976).

A fixação assimbiótica de nitrogênio é extremamente baixa, e não responde à adição de matéria orgànica. Fato que não surpreende, visto as condições desfavoráveis encontradas para os fixadores nestes solos, pH baixo, teores tóxicos de elementos como alumínio, ALEXANDER (1961). E conhecida que a associação entre bactérias celulolíticas e fixadoras de nitro gênio ë benefica aos dois processos, o que provavelmente não ocorre nestes solos, pois os dois grupos funcionais são escassos. Espécies de Beijerinckia crescem bem em $\mathrm{pH}$ ácido, chegando mesmo a se desenvolver em $\mathrm{pH} 3,0$, Clostridium apresenta uma exigência intermediäria, DOMMERGUES e MANGENOT 
(1970). Um outro fator limitante talvez seja a escassa presença de substân cias energeticamente ricas, que são essenciais à fixação, AIEXANDER (1961), DöBEREINER (1959), ASCENC̆ÕO et alii (1977). Não foi avaliada a fixação sim biótica no presente estudo, mas SILVA (1977) salienta que a abundância de leguminosas entre a vegetação nativa de cerrado, evidencia que espécies de Rhizobium estejam adaptadas às condições de solos de cerrado, apesar de seu baixo pH e toxidez por alumínio.

\subsection{Micro Neubauer}

No método de Neubauer modificado por CATANI e BERGAMIN(1961), Quadro 13, notou-se que houve diferença significativa entre os tratamentos. No solo incubado em aerobiose, após 3 meses observou-se 3 grupos distintos: Um grupo onde a produtividade foi maior, composta de $R$. exaltata e E. robus ta, evidenciando uma mineralização mais rápida, P. elliottii com uma produtividade intermediária, e um grupo composto de C. bracteosa, Caesalpina spp. e o solo sem adição de matéria orgânica. Resultados que confirmam observações de SCHREVEN (1964), MISHUSTIN e MIRSOEVA (1968), CALLE e VELASCO (1971), VELASCO et alii (1974) de que a taxa de mineralização depende do ti po de resíduo adicionado. Após seis meses, os melhores tratamentos foram os de P. elliattii e C. bracteosa cujo conteúdo de C tendeu a aumentar nes te período quando comparado com o anterior (Quadros 15 e 16), em seguida es tão os tratamentos com $R$. exaltata e E. robusta, cujo $C \%$ diminui neste período, evidenciando a sua rápida mineralização e imobilização, o solo trata do com resíduo de Caesalpina spp.., teve sua produtividade mais baixa que o solo testemunha, provavelmente devido ao toxidez de Al, Quadros 15 e 16. 
Em anaerobiose, C. bracteosa manteve-se com maior produtividade nos três e seis meses. Aos três meses a diferença entre os tratementos foi muito pequena. Observa-se, pelos dados, que a decomposição do resí duo é mais lenta, confirmando afirmação de RHAN (1913), citado por MACLAREN e SKUJINS (1968), ALEXANDER (1971), GREENWOOD (1961), GREENWOOD (1968) e SWABY $(s / d)$.

\subsection{Anālise da fertilidade dos solos}

Na análise da fertilidade dos solos, foi utilizado para fins comparativos, os níveis citados por CATANI e JACINTO (1974), após 3 meses notou-se um maior aumento no $\mathrm{pH}$ em E. hobusta, o que coincide com um teor em Ca trocável maior que nos outros solos. Todos os tratamentos apresentam acidez média, com excessão do solo sem adição de resíduo vegetal e do trata mento com Caesalpina spp. Após 6 meses não houve uma modificação brusca no $\mathrm{pH}$, notando-se em anaerobiose uma tendência de aumento do pH no solo.

0 aumento do $\mathrm{pH}$ no solo onde foi adicionado matériaorgânica, deve-se provavelmente ao aumento da amonificação. E a redução do Al trocável, quando comparado com o solo sem adição de resíduo vegetal, e o que recebeu resíduo Caesalpina spp. (Quadro 16).

Logo após 3 meses de incubação, o C\% mostrou-se alto, e aumentou em todos os tratamentos, comparando-se com a testemunha. Após 6 meses, mateve-se este quadro, observando-se uma tendência de, em anaerobiose, haver um maior aumento de $C \%$, tendēncia esta já esboçada aos três meses. Talvez devido ao fato de que em anearobiose os compostos carbonados são me- 
.65 .

tabolizados parcialmente, resultando compostos orgänicos inturmediários, SWABY (s/d), SKINER (1968).

o fósforo mostrou-se muito baixo, reforçando a hipótese de que o mesmo seja limitante a vários grupos funcionais do solo. Observou-se um nível um pouco acima dos demais, mas que ainda assim é baixo, em solos onde foi adiconado Pinus. Esta provavelmente é uma das causas para uma maior produção após 6 meses no solo incubado em aerobiose. O potássio foi incrementado, atingindo níveis altos nos solos tratados com matéría orgânica, e no solo testemunha manteve-se baixo. O cálcio trocável foi baixo em todos os tratamentos no decorrer dos 6 meses de incubação, sendo mais eleva do em E. robusta, o que talvez explique o maior aumento do pH neste tratamento.

o nível de magnésio foi médio em E. robusta, talvez pela maior riqueza do referido metal neste resíduo (ver análise da M.O.), nos de mais tratamentos foi baixo, embora diferindo do solo sem adição de matéria orgânica.

o alumínio foi baixo em solo de E.robusta desde o início, e tam bém em Pinus após 6 meses de incubação, foi alto no solo original e com adi ção de Caesalpina spp. após 3 meses e de C. bracteosa após 6 meses, nos demais manteve-se médıo.

O teor mais elevado de Al nestes tratamentos deve-se ao fato que os vegetais são típicos de cerrado, são plantas perenes e acumulam alumínio durante o seu desenvolvimento, ARENS et alii (1958). 
o nível de protors fol médio em todos os tratamentos, mesmo para o solo testemunha, e em E. rabusta tendendo para baixo.

\subsection{Avaliação de fósforo solúvel}

Na avaliação de fósforo solüvel em água após Incubação por 7 e 15 dias não se obteve diferenças significativas, apresentando um alto coe ficiente de variação (Quadro $n^{\circ} 14$ ), o que impede qualquer conclusão.

Na estração do fósforo por ácido, aos 7 dias de incubação, não houve diferenciação entre os tratamentos, a não ser quando comparado com o solo testemunha. Apọs 15 dias de incubação, notou-se uma pequena solubilização no solo com resíduo de E. robusta, mas não diferindo significativamente do solo sem resíduo vegetal e com fósforo. observou-se também uma pequena imobilização de fósforo nos tratamentos com resíduo vegetal. 


\section{RESUMO E CONCLUSOEES}

No presente trabalho, foram avaliados os grupamentos funcionais do ciclo do carbono: amilolíticos, celulolíticos, e hemicelulolíticos, e os do ciclo do nitrogênio: proteolíticos, amonificantes, nitrificantes, denitrificantes e fixadores de nitrogênio, em solos de cerrado onde foram adicionados resíduos vegetais de espécies nativas: Rhynchospora exaltata, Caesalpina bracteosa e Caesalpina spp., assim como espécies comumente utili zadas em reflorestamentos: Eucaliptus robusta $s . m$., Pinus elliottii Elgen var. elliottii. A incubação foi feita em condições de 60\% e 110\% da capaci dade de campo, em temperatura que oscilou entre 27 e $34^{\circ} \mathrm{C}$. Foram realizadas análises de fertilidade e produtividade do solo durante o período de in cubação, que foi até 6 meses. Paralelamente foram realizados experimentos com adição de fosfato de rocha nos tratamentos citados, em períodos de incubação de 7 e 15 dias.

Baseados nos resultados obtidos de avaliação do numero mais provável de microrganismos nos grupos funcionais do ciclo do carbono e ni- 
trogênio, método de micro-Neubauer (produtividade), análise de fertilidade dos solos e incubação do solo com fosfato de rocha, foram obtidas as seguin tes conclusões:

a. a incubação do solo com diferentes resíduos vegetais, alterou os vários grupos funcionais de microrganismos do solo, tanto em aerobiose com em anaerobiose. Consequentemente houveram alterações nas populações, fertilidade e produtividade dos solos;

b. no ciclo de nitrogênio, em todos os tratamentos, foram ob servadas alterações nos grupos funcionais, onde uma baixa população de nitrificantes está associada a uma alta população de amonificantes, o que sugere a possibilidade de acúmulo de $\mathrm{N}$ amoniacal no solo.

c. no ciclo do carbono houve diferenças entre a incubação ae róbia e anaeróbia, nesse último havendo um acúmulo de compostos intermediärios. Em todos os casos a população de celulolíticos foi muito baixa.

d. a adição de resíduo vegetal, levou a uma melhoria na produtividade e na fertilidade do solo, avaliados respectivamente pelos métodos de micro-Neubauer e análise química do solo, aumentando o pH e reduzindo o Al livre, evidenciando sua importáncia na reciclagem de nutrientes, principalmente em solos carentes, como são os de cerrado. 


\section{SUMMARY AND CONCLUSIONS}

In this work, miorobial functional groups $1 \mathrm{n}$ the oarbon oyole - V1z: amylolytics, cullololytics, hemicellulolytice; and those of the n1trogen oyole - proteolyt1cs, ammonificants, nitrificants, denitrifioants and nitrogen fixers were analysed in the "cerrado" type of soll in which plant residues of Rhynchospona exaltata, Caesalpina bracteosa, Caesalpina spp. (al1 nat1ve spec1es), and Eucalyptus robusta s.m., Pinus ellottil E1gen var. elliottil (varieties that are normally used in reforestation), had been added.

Incubation was done at 60 and $110 \%$ fleld capacity at temperatures that varied between 27 and $34^{\circ} \mathrm{C}$. Fertility and produotivity of the soll were analysed during an incubation perlod that lasted 6 months. At the same time similar experiments were realised but with the addition of rock phosphate to the soll and Incubation period of 7 to 15 days.

Based on the results obtained from the evaluation of the most probable number of microorganisms in both carbon and nitrogen cycles, 
the method of micro-Neubauer (for productivity), the analysis of fertility of soils and the incubation of soil rock phosphate, the following conclusions were arrived at:

a. Incubating the soil with different plant residues altered the microbial functional groups both aerobic and anaerobic. As a result, there was a change in the microbial populations, fertility and productivity of the soils.

b. In the nitrogen cycle like in all other treatments, alterations in functional groups were observed where low nitrificant populations are associated with a high population of ammonificants suggesting a possible accumulation of ammoniacal nitrogen in the soil. c. As to the carbon cycle there was a difference between aerobic and anaerobic incubations; in the, latter there was a accumulation of intermediary compounds. In all cases the populations of cellulolytic microorganisms was quite low.

d. Addition of plant residues to the soil resulted in higher fertility and productivity (as demonstrated by chemical and micro-Neubauer analyses of the soil), increased $\mathrm{pH}$, and reduction of free aluminium. All the above showed their importance in nutrient recycling principally in deficient soils like the "cerrado" type. 


\section{LITERATURA CITADA}

ADAMCZYC-WINIARSK, 2.; M. KROL e J.P. KOBUS, 1975. Microbial oxidation of elemental sulfur in brown soil. Plant Soil, 43(1): 95-100.

ALEXANDER, M., 1961. Introduction to soil microbiology. U. States, editor JOHN WILEY \& SONS, INC., 472 p.

ALEXANDER, M., 1964. Biodegradation: problems of molecular recalcitrante and microbial fallibility. Adv. Aplz. Microbiol., 2: 35-80.

ALEXANDER, M., 1968. Degradation of particides by soil bacteria. In: Gray, T.R.G. e D. Parkinson, Ed. The ecology of soil bacteria. Liverpool, Liverpool University Press, p. 270-284.

ARENS, K.; M.G. FERRI e L.M. COUTINHO, 1958. Papel do fator nutricional na Economia d'água de plantas do cerrado. Rev. Biol. Lisboa, 1:313-324. ARZOLLA, J.D.P., 1959. Contribuição ao estudo da nitrificação de Aspergil lus wentii, Whemer. Piracicaba, ESALQ/USP, 74 p. (Tese de Livre-Docência). 
ASCENÇÃO, A.R.; L. DE VASCONCELOS; M.F.F. FARIA e A: DROZDOWICZ, 1977. Survival of nitrogen fixing bacteria in cerrado soils. In: International Symposium on the limitations and potentials of biological nitrogen fixation in the tropics. Ed. by DöBEREINER, J.; R.H. BURRIS: D.B. SCOTT e A. HOLLAENDER, p. 85. Universidade de Brasilia, Brasil.

ASKINAZI, D.L., 1958. The possible role of microorganisms in increasing. The effectiveness of ground rock phosphate as a fertilizer. Soviet Soil Science, 4: 372-379.

AUGIER, J., 1956. A propos de la enumeration des Azotobacter en mileu liquide. ANN. INST. PASTEUR. 91: 759.

AUGIER, J., 1957. A propos de la fixation biologique de l'azote atmosphérique, et la numeration des clostridium fixateurs dans les sols. ANN. INST. PASTEUR. 92: 817-824.

BACON, J.S.D., 1968. The chemical enviroment of bacteria in soil. In: GRAY, T.R.G. D. PARKINSON, Ed. The ecology of soil bacteria. Liverpool, Liverpool University Press, p. 25-43.

BAREA, J.M.; A. RAMOS e V. CALLAO, 1970. Incidence of phosphate-mineralizing microorganisms in soils of Granada. Microbiologia esp.. 23: 149-156.

BARJAC, H., 1952. La puissance denitrificante du sol mise au point d'une technique d'evaluation. ANN. INST. PASTEUR. 83: 118-125.

BARJAC, H. e M.A. CHALVIGNAC, 1954. Nouve essai sur la determínation du pouvoir amylolytique. Annls. Inst. Pasteur. Paris, 87: 84-89. 
BASU, S.N. e S.N. GHOSE, 1960. The production of cellulase by fungi on mixed cellulosic substrates. Can. J. Microbiol., 6: 265-282.

BERTRAND, D., 1972. Interactions between mineral elements and soil microoganisms. Revue d'Ecologie et de Biologie du Sol. $9(3)$ : 349-396.

BIEDERBECK, V.O. e C.A. CAMPBELI, 1973. Soil microbial activity as influenced by temperature trends and fluctuations. Can J. Soil Sci., 53: $363-376$.

BIRCH, H.F., 1958. The effect of so11 drying on humus decomposition and nitrogen availabil1ty. Plant and Sol2, 10: 9-31.

BeåLFAVE, G., 1962. N1trogen fixation in cultures of algae and other organisms. Physiologia PZ., 15: 122.

BOLLAG, J.M.; M.L. ORCUTT e B. BOLLAG, 1970. Denitrification by isolated soil bacteria under various enviromental conditions. Soil Sci. Soc. Amer. Proc., 34: 875-879.

BöNISCHOVA-FRANKLOVA, S. e B. NOVAK, 1970. The effect of different temperatures on the transformation of organic matter by soil microflora. Pedobiologia, 10: $373-380$.

BOUGHY, A.S.; P.E. MUNRO; J. MEIKLEJOHN; R.M. STRANG e J.M. SWIFT, 1964. Antibiotic reactions between Africa savanna species, Nature, Lond., 203: $1302-1303$ 
BOWMAN, R.A. e D.D. FOCHT, 1974. The influence of glucose and nitrate concentrations upon denitrification rates in sandy soils: Soil Biology \& Biochemistry, 6[(5): 297-301.

BOWEN, G.D., 1961. The toxicity of legume seed diffusates toward rhizabia and other bacteria. Pl. Soil., 15: 155.

BRADLEY, D.B. e D.H. SIELING, 1953. Effect of organic anions and sugar on phosphats precipitations by pH. Soil Sci., 76: 175.

BRANDT, G.M.; A.R. WOLCOTT e A.E. ERICKSON, 1964. Nitrogen transformations in soils as related to structure, moisture and oxygen difusion rate. Proc. Soil Sci. Soc. Ami, 28: 71.

BRISTOL, B.M., 1919. On the retention of vitality by algae from old stored soils. New Phytol., 18: 92.

BROWN, M.E.; R.M. JACKSON e S.K. BURLINGHAM, 1968. Growth and effects of bactéria introduced into soil. In: GRAY, T.R.G. e D. PARKINSON, Ed. The ecology of soil bacteria. Liverpool, Liverpool University Press, p. 531$-551$.

CALLE, J.M.L., 1968. Influència de diversos factores ambientales y edaficos, sobre la actividad microbiana. Anales de Edafologia y Agrobiologia. Ma drid, $27(11-12)$

CALLE, J.M.L., e F. VELASCO, 1971. Microbial population and humus types in semiarid soils. Anales de Edafologia y Agrobiologia. Madrid, 30 $(3 / 4) \div 285-292$. 
CALLE, J.M.L. e F. VELASCO, 1972. Alteraciones sinecológicas de la poblacion microbiana en um antigo bosque de Quercus toza Bash., repoblado con Pinus pinaster Sol. Anales de Edafologia y Agrobiologia. Madrid, 31 $(7 / 8): 615-624$.

CAMPBELL, C.A.; V.O. BIEDERBECK e F.G. WARDER, 1970. Stimulated early spring thaw conditions infusious to soil microflora. Can. J. Soil Sci., 50: $257-259$.

CAMPBELL, C.A. e V.O. BIEDERBECK, 1972. Influence of flutuating temperatures and constant soil moistures on nitrogen changes in amended and unamended loam. Can. J. Soiz. Sci., 52: 323-336.

CARVALHO, P.C.T.; A.F. EIRA e O. PELLEGRINO, 1969. Solubilização quantita tiva de fosfatos insolúveis, por algumas espécies dos gèneros, Aspergillus e Penicillium. Anais da ESALQ-USP. Piracicaba, SP, 26: 173-185.

CARVALHO, P.C.T.; J.M. SALGADO e E.P. DE SANTANA, 1977. Biotransformação da apatita de Araxá em solo suplementado com diferentes fontes de carbono. Revista O Solo. Piracicaba, 69: (11) 30-34.

CASIDA, L.E. Jr., 1959. Phosphatase activity of some common soil fungi. Soit Sci., 87: 305-310.

CATANI, R.A. e A.O. JACINTO. 1974. Avaliação da fertilidade do solo. Métodos de anälise. Piracicaba. Livroceres, $61 \mathrm{p}$.

CATANI, R.A. e H. BERGAMIN FO, 1961. Sôbre uma modificação do método de Neubauer. Anais da ESALQ. Piracicaba, 18: 287-300. 
CHALVIGNAC, M.A., 1953. Mesure des pouvoirs amylolytique at protéolytiques des terres en aérobiose. Ann. Inst. Pasteur. Paris, 84: 816-819.

CHASE, F.E.; C.T. CORKE e J.B. ROBINSON, 1968. Nitrifing bacteria in soil. In: GRAY, T.R.G. E D. PARKINSON, Ed. The ecology of soil bactemia. Liverpool, Liverpool University Press, p. 591-611.

CLARK, F.E., 1968. The growth of bacteria in soil. In: GRAY, T.R.E. e D. PARKINSON. The ecology of soil bacteria. Liverpool, Liverpool University Press, $P, 441-457$.

COOPIER, 0. e H. BARJAC, 1952. De la richease d'un sol en microorganismes nitrificateurs. Ann. Inst. Pasteur, 83: 118-125.

CROCOMO, J.0., 1967. Transformações metabölicas em microorganismos. Curi tiba, Instituto de Bioquímica da Universidade Federal do Paraná. 165 p. CURRIE, J.A., 1962. The importance of aeration in providing the right conditions for plant growth. J. Sei. Food Agric., 13: 380.

DABAN, B., 1976. Composição química e formação dos produtos húmicos no so 10. In: 10 Colóquio sobre matéria orgânica no solo. Piracicaba.

DE, S.K.: S. ALI e S. CHANDRA, 1972. Changes in the quantities of soil organic carbon in presence of ammonium salts. Indian J.Agric. Chem., 5: $61-68$.

DEL WICHE, C.C. e B.A. BRYAN, 1976. Denitrification. Ann. Rev. Microbiol. 30: $241-262$. 
DöBEREINER, J., 1959. Influéncia da cana-de-açúcar na população de Beijerinckia no solo. Rev. Brasil. Biol., 19(3): 251-258.

DöBEREINER, J. e R. ALVAHYDO, 1966. Eliminação da toxidez de manganès em solo "gray hidromórfico" pela matéria orgãnica. Pesq. Agropec. Bras., 1: $243-248$.

DöBEREINER, J., 1977. Potential for nitrogen fixation in legumes and grasses. In: International Symposium on the limitations and potentials of biological nitrogen fixation in the tropics. Ed. by DöBEREINER, J.; R.H. BURRIS; D.B. SCOTT e A. HOLLAENDER. p. 34. Universidade de Brasilia, Brasil.

DOMMERGUES, Y. e F. MANGENOT, 1970. Ecologie microbienne du sol. Paris, Masson et Cie, Éditeurs. 796 p.

EIRA, F.A. e P.C.T. CARVALHO, 1970a. A decomposição da matéria orgânica pelos microorganismos do solo, e sua influência nas variações do $\mathrm{pH}$. $R e-$ vista de Agricultura, 45: 15-21.

EIRA, A.F. e P.C.T. CARVALHO, 1970b. Levantamento de microorganismos solu bilizadores de fosfato. Rickia, 5 : 111-124.

ESCOBAR, E.; M. NESTOR e M. BLASCO, 1972. Mineralizacion del carbono y ni trogeno en los suelos del Putumayo, Amazonas Colonbiano. Efectos de la celulosa y temperatura. Turrialba, 22(1): 47-52. 
FABRAUES, G. e H. LJUNGGREEN, 1968. Pré-infection phases of the legume symbiosis. In: GRAY, T.R.G. e D. PARKINSON, Ed., The ecology of soil bacteria. Liverpool, Liverpool University Press, p. 396-421.

FREIRE, J.R.J., 1975. Microbiologia do solo. Faculdade de Agronomia. U.F.R.G.S. Porto Alegre, 234 p.

GIRARD-ROGIEUX, 1964. Técnicas de Microbiologia agricola. Zaragoza, editorial Acríbia. $267 \mathrm{p}$.

GOODLAND, R.J.A., 1971. Oligotrofismo e alumínio no cerrado. In: Ferri. M.G. Coord. Simpósio sobre cerrado. 3a. ed. São Paulo, Ed. Edgard Blücher, P. 45-60.

GRANS, W.T., 1975. The relation between organic matter content and exchangeable aliminium in acid soil. Soil Sci. Amer. Proc., 39(1): 591. GRAY, T.R.S. e S.T. WILLIAMS, 1971. Soil microorganism. University Reviews in Botany. Ed. by Professor V.H. Heywood, Ph.D, D. Sc., 240 p. GREENWOOD, D.J., 1961. The effect of oxygen concentration of the decomposition of organic materials in soil. Plant Soil, 14: 360-376.

GREENWOOD, D.J., 1962. Nitrification and nitrate dissimilation in soil. II. Effect of oxygen concentration. Plant Soil, 17: 378-391. 
GREENWOOD, D.J., 1968. Measurement of microbial metabolism in soil. In: GRAY, T.R.G. E D. PARKINSON, Ed. The ecology of soil bacteria, Liverpool, liverpool University Press, p. 138-157.

HAYMAN, D.S., 1975. Phosphorus cycling by soil microorganisms and plant roots. In: WALKER, N., Ed. Soil microbiology. A critical review, London, p. 67-91.

HIRIE, W.F., 1972. Influence of organic matter on the heterotrophic bacteria in different solls. In. Proceedings of the Symposium on soll microbiology. Symposia Biologica Hungarica, 11: 221-227.

HEILMAN, D., 1974. Effect of urea fertilization on nitrification in forest soils of the Pacific North West. Soil Sci. Soc. Amer. Proc, 38 (4): $664-667$.

HODSON, P.H., 1973. The role of phosphorus in bacteria and viroses. In: Environmental phosphorus Hand Book. John Willey \& Sons ed. p. 451-474. HOLDING, A.J. e D.C. JEFFREY, 1868. Effects of metallic ions on soil bacteria. In: GRAY, T.R.G. e D. PARKINSON, Ed. The ecology of soil bacteria. Liverpool, Liverpool University Press, p. 516-530.

IMSHENETSKY, A.A., 1968. Decomposition of cellulose in the soil. In: GRAY, T.R.G. E D. PARKINSON. Ed. The ecology of soil bacteria. Liverpool, Liverpool University Press, p. 256-269.

JAYARAMAN, K.N. e N.N. PRASAD, 1972. Production of phosphatase by soil Aspergilli. Madras Agricultural Journal, 59: 640-641. 
JOHNSON, D.D. e W.D. GUENZI, (s/d). Influence of salts on ammonium oxidation and carbon dioxide evolution from soil. Proc. Soil Sci. Soc. Amer., 27: 663.

JUMA, N.G. e M.A. TABATABAI, 1977. Effects of trace elements on phosphatase activity in soil. Soir Sci. Soc. Am. J., 41: 343-346.

JUSTICE, J.K. e R.L. SMITH, 1962. Nitrification of ammonium sulfate in a calcareous soil as influenced by combinations of moisture, temperature and levels of added nitrogen. Proc. Soil Sci. Soc. Am., 26:246.

KIEHL, J.C. e J.V.C. ROCHA FILHO, 1972. Adubação do trigo com amônia anidra. Revista de Agricuitura, 47(2): 75-80.

KIEHL, J.C. e A. COBRA NETO, 1976. Nitrificação da amônia em alguns solos do município de Piracicaba. Revista o Solo, 68 (2): 32-39.

KOIKE, H., 1961. The effects of fumigantes on nitrate production in soil. Proc. Soil Sci. Soc. Am., 25: 204.

KONG, K.T. e Y. DOMMERGUES, 1973a. Cellulolysis limitation in organic soils. II. A study of soil enzymes. Revue d'Ecologie et du Biologie du sol, 9 : 629-640.

KONG, K.T. e Y. DOMMERGUES, 1973b. Limited cellulolysis in organic soils. III. Competition between cellulolytic and non-cellulolytic microflora in organic soils. Revue d'Ecologie et de Biologie du sol, 10: 45-53.

KRASILNIKOV, N.A., 1968. Sanitation of soil by microorganisms, In: GRAY, 
T.R.G, E D. PARKINSON, Ed. The ecology of soil bacteria. Liverpool, Liverpool University Press, p. 422-438.

KUBISTA, K., 1972. Effect of organic matter, aeration and bentonite on microorganisms and plants. In: Proceedings of the Symposium on soil microbiology. Symposia Biologica Hungarica, 11: 229-235.

LAJUDIE, J. e M.A. CHALVIGNAC, 1956. Appréciation de l'activité protéolytique de la microflora du sol. Ann. Inst. Pasteur, 90: 359-361.

LOCKWOOD, J.L., 1959. Streptomyces spp. as a cause of natural fungitoxicity in soils. Phytopathology, 49: 327.

LOCKWOOD, J.L. e B.T. LINDAPA, 1963. Fungitoxicity of sterilized soil incubated with soil microflora. Phytopathology, 53: 917.

LOEWENSTPIN, H.; L.E. ENGELBERT; O.J. ATTOE e O.N. ALLEN, 1957. Nitrogen loss in gaseous forms soils as influenced by fertilizers and management. Proc. Soil Sci. Soc. Am., 21: 397.

LOTT, W.L.; J.P. NERY; J.R. GALLO e J.C. MEDCALF, 1956. A técnica de anälise foliar aplicada ao cafeeiro. IBEC Research Institute, $n^{\circ} 9$. LOURES, E.G.; A.R. CONOE e J. ALENCAR, 1976. Efeito de uma Pseudomonas sp. oligonitrofila na estabilidade de agregados do solo. Revista Ceres, 23 $(129): 364-373$.

MACFADYEN, A., 1968. The animal habitat of soil bacteria. In: GRAY, T.R. G. e D. PARKINSON, Ed. The ecology of soil bacteria. Liverpool, Liver- 
pool University Press, 66-76.

MACLAREN, A.D. e J. SKUJINS, 1968. The physical environment of micro-organisms in soil. In: GRAY, T.R.G. e D. PARKINSON, Ed. The ecology of soil bacteria. Liverpool, Liverpool University Press, p. 3-24.

MACURA, J., 1968. Physiological studies of rhizosphere bacteria. In: GRAY, T.R.G. E D. PARKINSON. The ecology of soit bacteria, Liverpool, Liverpool University Press, p. 379-395.

MADAN, M., 1974. Microbial dissolution of phosphates. Indian J. Microbiol. $14(4): 167-172$.

MISHUSTIN, C.N. e V.A. MIRSOEVA, 1968. Spore forming bacteria in the soils of the USSR. In: GRAY, T.R.G. e D. PARKINSON, Ed. The ecology of soil bacteria. Liverpool, Liverpool University Press, 458-473.

MITCHELL, R. e M. ALEXANDER, 1963. Lysis of soil fungi by bacteria. Can. J. Microbiol., 9: 169.

MOKWUNEY, UZO, 1975. The influence in pH of soils from savannah zones of Nigéria. Soil Sci. Soc. Proc., 39 (2): 1100-1102.

OLUTIOLA, P.O., 1968. Cellulase enzymes in culture filtrates of Ceratocystis paradoxa. Mycologia, 68(5): 1083-1092.

PERES, J.R.R.; A.R. SUHET e D.M.G. DE SOUZA, 1977. Biological fixation of atmospheric nitrogen in some brazilien cerrado soils, preliminary observations. In: International Symposium on the limitations and potentials of biological nitrogen fixation in the tropics. Ed. by 
DöBEREINER, J.; R.H. BURRIS; D.B. SCOTT \& A. HOLLAENDER. p. 107. Universidade de Brasilia, Brasil.

POCHON, J. e P. TARDIEUX, 1962. Techniques d'analyse on microbiologie du sol. Editions de la Tourelle, Paris, III, $111 \mathrm{pg}$.

POCHON, e. e P. TARDIEUX, 1968. Enrichement and the elective cul vation of bacteria. In: GRAY, T.R.G. e D. PARKINSON Ed. The ecology of soir bacteria. Liverpool, Liverpool University Press, p. 123-137.

PURCHASE, B.S., 1974. The influence of phosphate deficiency on nitrification. Plant and Soir, 41 (3): 541-547.

QUERO, F.G., 1943. Compendio de microbiologia del suelo. Processos biológicos do solo. Instituto Florestal de Investigaciones y Experiéncias. Madrid.

REESE, E.T. e H.S. LEVINSON, 1952. Comparative study of breakdown of cellulose by microorganisms. Physiol. Plantamon, 5: 345-366.

RICE, E.I., 1964. Inhibition of nitrogen-fixing nitrifying bacteria by seed plants. I. Ecology, 45: 824.

RICE, E.I., 1965. Inhibition of nitrogen-fixing and nitrifying bacteria by seed plants. II. Characterization and identification of inhibitors. Physiol. Plant., 18: 255-268.

ROBINSON, J.D., 1963. Nitrification in a New Zealand Grassland soil. PZ. Soir, 19: 173-183. 
ROSS, J.D. e B.A. BRIDGER, 1977. Factors influencing nitrogen mineralization in Taita hill soil, a central yellow-brown earth under grazed pasture. N.2. Journal of Agricultural Research, 20 (2): 193-203.

ROVATT, J.W., 1968. Nutritional classifications of soil bacteria and their value in ecological studies. In: GRAY, T.R.G. e D. PARKINSON, Ed. The ecology of soil bacteria. Liverpool, Liverpool University Press. $P .360-376$.

ROVIRA, A.D. e E.H. RIDGE, 1973. Exudation of ${ }^{14} \mathrm{C}$-labelled compounds from wheath roots: influence of nutrients, microorganisms and added organic compounds, New Phytol., 72: 1081-1087.

RUSSELL, E.W., 1968. The agricultural environment of soil bacteria. In: GRAY, T.R.G. E D. PARKINSON. The ecology of soil bacteria. Liverpool, Liverpool University Press, p. 77-89.

SANTOS, O.M., 1977. Biodinâmica de um ecossistema de solo de tabuleiro da região sul do Estado da Bahia. Universidade Federal da Bahia, 87 p. (Te se de mestrado).

SCHREVEN, D.A. VAN, 1964. A comparison between the effect of fresh and dried organic materials added to soil on carbon and nitrogen mineralization. Plant and soir, 20: 149.

SHIELDS, I.M. e H. DURRIEL, 1964. Algae aeration to soil fertility. Bot. Rev., 30: 92 . 
SILVA, A.R. da,1977. Cerrado: region of high agricultural potential and requiring nitrogen. In: International symposium on the limitations and potentials of biological nitrogen fixation in the tropics. Ed. by Do̊BEREINER, J.; R.H. BURRIS; D.B. SOTT e A. HOLLAENDER, P. 5-14. Universidade de Brasilia, Brazil.

SKINER, F.A., 1968. The anaerobic bacteria of soil, In: GRAY, T.R.G. e D. PARKINSON, Ed. The ecology of soil bacteria. Liverpool, Liverpool University Press, p. 573-592.

SMILEY, R.W. e R.I. PAPENDICK, 1967. A portable injector for dispersing liquid anydrous $\mathrm{NH}_{3}$ in the field. Soil Sci. Soc., 32: 729-731.

SMITH, J.H. e G.R. BURNS, 1965. Ion gradients and nitrification associated with decomposition of plants material layer in soil. Soil Sci. Soc. Proc. 29: $179-181$.

SMITH, K.A., 1977. Soil aeration. Soil Science, 123(5): 284-291. SPURR, S.H., 1940. The influence of two juniperus species on soil reaction. Soil Science, 50: 289-294.

STANFORD, G.; M.H. FRERE e D.H. SCHWANINGER, 1973. Temperature coefficient of soil nitrogen mineralization. Soil Sci., 115: 321-323.

STENVENSON, I.L., 1956. Antibiotic activity of actinomycets in soil as demonstrated by direct observation techniques. J. Gen. microbiol., 15: 372 . 
STIVEN, G., 1852. Production of antibiotic substanaes by the roots of a grass Trachypojon phimorus (H.B.K.) Nus. and of Pentanisia variabilis (E. Mey.) Harv. (rubiaceae). Nature. Lond., 170: 712-713.

STOJANOVIC, B.J. e M. ALEXANDER, 1958. Effect of inorganic nitrogen on nitrification. Soil Sci., 86: 208.

SWABY, R.J., (s/d). Stability of soil inorganic matter and its significance in pratical agriculture. In: Organic matter and soil fertility. JOHN WILEY \& SONS, InC., NeW York, USA, 583-604.

SZEMBER, A.; B. WOYTOWICZ e W. JASKIEWICZ, 1972. The influence of light soil fertilization with bentonite on the growth of cellulolytic fungi. Polish Joumal of Soil Science, 5: 77-83.

TABOADA, J.: M. ULLOA e T. HERRERA, 1973. Fijación de nitrógen in vitro por Agrobacterium azotophillum en diversos substratos, principalmente tierra y derivados de la industria azucarera. Rev. Lat. comer. Microbiol., 15: $143-146$

TAHA, S.M.; M.A.Z. MAHMOUD e A. EL-DAMATY, 1969, Activity of phosphate dissolving bacteria in Egyptian Soils. Plant.Soil, 31: 149-160.

TESAROVA, M., 1971. Effect of nitrogen form on cellulose decomposition at different levels os soil moisture. Zentralblatt für Backteriologie, Parasiten Kunde, infektionskhankheiten und Hygiene, Zweite Abteihung, $126(4): 409-419$. 
TESAROVA, M. 1971. Utilization of $N, P$ and $S$ additions by the cellulolytic microflora of some grassland soils. Folia microbiologica, 16: 514.

THEOBALDI, W.F. e W.H. SMITH, 1974. Nitrate production in two soils and nitrate reducing in Pine. Soil Sci. Soc. Amer., 38: 668-672.

TODOROVA, B. e M. BENEVSKI, 1971. Changes in the cellulose decomposing activity of leached chermozem-smonitza in the presence of various forms of nitrogen and phosphorus fertilizers. Pochv. Agrokhim., 5(5): 57-63.

TOSIN, J.C.; J.M.G. FERRAZ; E. DE ASSUMPGÃO; O.C.R. GOMES E P.C.T. CARVALHO, 1976. Influência do Pinus elliottii Engelm, Araucaria angustifolia (Bert.) 0. Ktze e da mata nativa sobre a atividade microbiana do solo. In: VII Congresso Brasileiro de Microbiologia, Porto Alegre, RS. 1976. TOSIN, T.C., 1977. Influência do Pinus elliottil Engelm., Araucaria angus tifolia Bert.) 0. Ktze. e da mata nat iva sobre a atividade microbiana do solo. Universidade Federal de Curitiba. 105 p. (Tese de Mestrado).

VELLASCO, F. e J.M.L. CALLE, ( $(s / d)$. Processos de humificacion, dinamica y catenas de suelos en la Sierra de Guadarrama. Anales de Edafologia y Agrobiologia. 347-358.

VELLASCO, F., L. VILLALBA e J.M.L. CALLE, 1974. Influência del extrato hidrosoluble de Juniperus thurifera L. sobre diversos microorganismos te luricos. Anales de Edafologia y Agrobiologia, 32 (1-2): 83-89.

VERONA, O. e A.A. LEPIDI, 1972. Decomposition of the outward woxy film of straw by soil micro-organisms. In: Proceedings of the Symposium on 
soil microbiology. Symposia Biologica Hungarica, 11: 55-58.

WEBER, D.F. e P.L. GAINER, 1962. Relative sensitivity of nitrifing organims to hidrogen ions in soils and solutions. Soil Sci., 94, 138-145.

WELCH, L.F. e A.D. SCOTT, 1960. Nitrification of fixed ammonium in clay minerals as affected by added potassium. Soil Sci., 90: 79.

YUEERA, E.P. e J.M.C. DORRIEN, 1973. Quimica agricola, solos e fertilizan tes. Editorial Aluambra, Madrid, 472 p. 
.89.

APENDICE 
Quadro 1. Anälise de variância do método de Micro-Neubauer aplicado à plan tas de arroz cultivadas em solos incubados durante 3 meses em ae robiose.

\begin{tabular}{lcccc}
\hline Causas da variação & G.L. & S.Q. & Q.M. & F \\
\hline Tratamentos & 5 & 0,88 & 0.17 & 10,09 \\
Residuos & 24 & 0,42 & 0,01 & \\
\hline Total & 29 & 1,30 & & \\
\hline
\end{tabular}

$C_{0} V_{0}=15,29 \%$

D. Padrão $=0,1324$

D.M.S $=0.2588$

QUADRO 2. Análise de variância do método de Micro-Neubauer aplicado à plan tas de arroz cultivadas em solos incubados durante 6 meses em ae robiose.

\begin{tabular}{lcccc}
\hline Causas da Variação & G.L. & S.Q. & Q.M. & $F$ \\
\hline Tratamentos & 5 & 2,55 & 0,51 & 31,46 \\
Resíduo & 24 & 0,39 & 0,01 & \\
\hline Total & 29 & 2,94 & & \\
\hline
\end{tabular}

C.V. $=10,91 \%$

D. Padrão $=0,1275$

D.M.S. $=0,2492$ 
Quadro 3. Análise de variância do método de Micro-Neubauer aplicado à plantas de arroz cultivadas em solos incubados durantes 3 meses em anaerobiose.

\begin{tabular}{lcccc}
\hline Causas da Variação & G.L. & S.Q. & Q.M. & $F$ \\
\hline Tratamentos & 5 & 0,22 & 0,04 & 5,77 \\
Residuo & 24 & 0,18 & 0,00 & \\
\hline Total & 29 & 0,40 & \\
\hline
\end{tabular}

C. V. $=11,32 \%$

D. Padrão $=0,0879$

D.M.S. $=0,1718$

Quadro 4. Análise de variância do método de Micro-Neubauer aplicado à plan tas de arroz cultivadas em solos incubados durante 6 meses em anaerobiose.

\begin{tabular}{lcccc}
\hline Causas da Variação & G.L. & S.Q. & Q.M. & F \\
\hline Tratamentos & 5 & 2,78 & 0,55 & 25,02 \\
Resíduo & 24 & 0,53 & 0,02 & \\
\hline Total & 29 & 3,32 & & \\
\hline
\end{tabular}

C.V. $=12,87 \%$

D. Padrão $=0,1492$

D.M.S. $=0,2917$ 
.92.

Quadro 5. Análise de variância do $P$ solúvel em ácido do solo incubado por 7 dias com fosfato de rocha.

\begin{tabular}{lcccc}
\hline Causas da Variação & G.L. & S.Q. & Q.M. & $F$ \\
\hline Tratamentos & 6 & 28,83 & 4,80 & 23,96 \\
Resíduo & 28 & 5,61 & 0,20 & \\
\hline Total & 34 & 34,45 & \\
\hline
\end{tabular}

C. V. $=20,59 \%$

D. Padrão $=0,4478$

D.M.S. $=0,8992$

Quadro 6. Anälise de variância do $P$ solüvel em ácido do solo incubado por 15 dias com fosfato de rocha.

\begin{tabular}{lcccc}
\hline Ceuses de Veriátio & G.L. & S.e. & Q.M. & $F$ \\
\hline Tratamentos & 6 & 25,66 & 4,27 & 42,52 \\
Residuo & 20 & 2,01 & 0,10 & \\
\hline Total & 34 & 28,47 & & \\
\hline
\end{tabular}

C.V. $=16,06 \%$

D. Padrão $=0,3171$

D.M.S. $=0,6368$ 
Quadro 7. Análise de variància do $P$ solúvel em ägua do solo incubado por 7 dias com fosfato de rocha.

\begin{tabular}{lcccc}
\hline Causas de Variação & G.L. & S.Q. & Q.M. & $F$ \\
\hline Tratamentos & 6 & 0,00 & 0,00 & 3,07 \\
Resíduo & 28 & 0,00 & 0,00 & \\
\hline Total & 34 & 0,00 & & \\
\hline
\end{tabular}

$C_{0} V_{0}=73,95 \%$

D.Padrão $=0,0006$

D.M.S. $=0,0013$

Quadro 8. Anảlise de variância do $P$ solúvel em água do solo incubado por 15 dias com fosfato de rocha.

\begin{tabular}{lcccc}
\hline Causas de Variaçäo & G.L. & S.Q. & Q.M. & $F$ \\
\hline Tratamentos & 6 & 0,00 & 0,00 & 0,00 \\
Residuo & 28 & 0,00 & 0,00 & \\
\hline Total & 34 & 0,00 & & \\
\hline
\end{tabular}

C. V. $=141,66 \%$

D. Padrão $=0,0019$

D.M.S. $=0,0039$ 